\title{
Evidence for multiphase water-escape during rafting of shelly marine sediments at Clava, Inverness-shire, NE Scotland
}

\section{Emrys Phillips* and Jon Merritt}

British Geological Survey, Murchison House, West Mains Road, Edinburgh EH9 3LA, Scotland, UK

*corresponding author

telephone: +44131-667-1000 fax: +44131-668-2683 e-mail: erp@bgs.ac.uk

\begin{abstract}
The Pleistocene shelly glaciomarine sediments exposed at Clava, near Inverness northeast Scotland occur in a series of thrust-bound rafts accreted at on the up-ice side of a bedrock high (150 m above OD) on the SE side of the valley of the River Nairn. These sediments originally formed part of a coarsening upwards deltaic or subaqueous fan sequence deposited in the marine fjord of the Loch Ness basin, located some $50 \mathrm{~km}$ to the SW. The geometry of these allochthonous rafts, coupled with the associated thrusting and large-scale folding of these bodies, are typical of many glacially-transported rafts described in the literature. However, at Clava, macroand microscopic evidence indicates that these ice-rafted sediments were not frozen, with liquefaction, hydrofracturing and water-escape occurring repeatedly during their transport and accretion. The presence of large-scale detachments within the sequence, has led to the development of a purely glacitectonic model for rafting at Clava. The detachments acted as a focus for fluid flow which lubricated these décollement surfaces, aiding in the subglacial transport of the rafts.
\end{abstract}




\section{Introduction}

Glacial rafts, 'floes' or 'megablocks' are defined as dislocated slabs of bedrock and/or unconsolidated sedimentary strata that have been transported from their original position by glacial action (Stalker, 1976; Christiansen and Whitaker, 1976; Ruszczynska-Szenajch, 1987; Aber, 1985, 1988; Broster and Seaman, 1991; Benn and Evans, 1998). Such rafts are typically very thin (up to a few tens of metres) in comparison to their aerial extent (up to several $100 \mathrm{~km}^{2}$ ), and may have been transported for just a few tens of metres up to several hundred kilometres. They generally occur as single, horizontal slab-like features, but may be stacked within conspicuous ice-pushed hills of various types (Aber, 1988; Benn and Evans, 1998). Although internally the rafts largely appear undeformed, they may be cut by shear zones, faults and breccia/cataclastic zones, or even folded. It was generally thought that rafts were detached and transported whilst frozen to the base of cold-based ice sheets, melting out slowly following stagnation and decay of the enclosing ice (Banham, 1975; Aber, 1988).

More recent studies of ice-rafted sediments and bedrock, have suggested that failure, leading to detachment, is associated with elevated pore-water pressures that may occur along water-rich décollement surfaces within the subglacially deforming layer (Moran et al., 1980; Aber, 1985; Broster and Seaman, 1991; Benn and Evans, 1998), at the base of the deforming layer (Kjær et al., 2006), or as a consequence of subglacial hydrofracturing by forceful upward dewatering (Boulton and Caban, 1995; Rijsdijk et al., 1999). The role played by pressurised pore-water during both subglacial and, to a lesser extent, proglacial deformation is increasingly being recognised within tectonised glacigenic sequences (Boulton et al., 1974; Boulton and Caban 1995; Hiemstra and van der Meer, 1997; Rijsdijk et al., 19999; van der Meer et al., 1999; Phillips and Auton, 2000; Boulton et al., 2001; Khatwa and Tulaczyk, 2001; Phillips, 2006, Baroni and Fasano, 2006; Phillips et al., 2007). Alternative rafting models, however, suggest that rafts generated as a result of thrusting associated with proglacial deformation, occurring within an imbricate thrust stack (thrust moraine) formed in front of the advancing glacier (Banham, 1975; Christiansen and Whitaker, 1976; Moran et al., 1980; Bluemle and Clayton, 1984; Ruszczynska-Szenajch, 1987).

Micromorphological analysis is increasingly being used as a principal tool in understanding the kinematics and geometry of subglacial and proglacial deformation (e.g. van der Wateren, 1995; Phillips and Auton, 2000; van der Wateren et al., 2000; 
van der Meer et al., 2003; Menzies et al., 2006, Phillips et al., 2007) and distinguishing between diamictons deposited in these environments (e.g. van der Meer and Laban, 1990; van der Meer et al., 1992, 1994; van der Meer 1993; Hart and Roberts 1994; van der Meer and Warren, 1997; Menzies, 2000; Carr, 2001; Hart and Rose 2001; Khatwa and Tulaczyk, 2001; Hiemstra and Rijsdijk, 2003; Carr et al., 2006). Consequently, the application of macrostructural field techniques, combined with detailed micromorphological and microstructural analysis could provide valuable insights into the mechanisms involved during the detachment, transport and emplacement of ice-rafted sediment and bedrock slabs.

In this paper we present the results of a detailed macro- and microscopic structural study of the glacitectonic features associated with the ice-rafted glacigenic and marine sediments exposed at Clava [NH 760 440], on the SE side of the valley of the River Nairn, NE Scotland (Fig. 1). These allochthonous rafts were transported northeastwards by ice emerging from the Great Glen during the build-up of the last ice sheet in Scotland (Merritt, 1992; Peacock, 1975; Gordon, 1993). Combined field and micromorphological evidence has allowed the development of a glacitectonic model for the detachment, transport and accretion of these soft-sediment rafts. This model involves initial thrusting and folding, followed by several phases of liquefaction and water-escape. Micromorphological evidence indicates that pressurised pore-water played a key rock in the transport of the ice-rafted sediments exposed at Clava.

\section{Regional significance of the Clava shelly marine sediments}

The Pleistocene sediments exposed at Clava, $9 \mathrm{~km}$ E of Inverness (NE Scotland), have been the focus of significant interest ever since the mid-Nineteenth Century when clay, underlying till, was found to contain a rich assemblage of undeformed, unstriated, cold-water marine shells. The marine clay, known as the Clava Shelly Clay, occurs at an altitude of $150 \mathrm{~m} \mathrm{OD}$ and was found to contain delicate paired valves and pebbles with attached epifauna, as well as shells with preserved periostraca (Fraser, 1883; Horne et al., 1894). Debate has focused on whether the Clava Shelly Clay was in situ, having formed in a glaciomarine environment that resulted from glacio-isostatically induced submergence (up to $160 \mathrm{~m} \mathrm{OD}$ ) at the margin of an expanding Early Devensian ice sheet, before global sea level had fallen substantially (Sutherland, 1981); or whether it had been transported eastwards by ice from the Loch 
Ness basin, where it had been deposited when local sea level had been no higher than about 18 m OD (Horne et al., 1894; Peacock, 1975) (see Gordon, 1993 for a summary).

Following a detailed re-examination of all known localities at Clava (see Fig. 1), Merritt (1992) concluded that the shelly sediments did indeed represent an assemblage of allochthonous rafts, transported eastwards by ice emerging from the Great Glen during the build-up of the last ice sheet in Scotland. The faunal assemblage (Graham et al., 1992), together with infinite conventional radiocarbon ages and mid-Devensian amino acid dates obtained on the shells, support the conclusion that the Clava Shelly Clay was deposited in a high-boreal to low-Arctic marine fjord setting during an early to mid-Devensian interstadial. Amino acid dates on shells from other raft sites in NE Scotland cluster between 40 and $60 \mathrm{ka}$ BP, equivalent to the Bø Interstadial of SW Scandinavia (Merritt et al., 2003, fig. 43). However, a small raft of shelly till present at Clava, contained unabraded paired valves of the Arctic bivalve Portlandia arctica and a broken, unabraded fragment of Mya truncate. This particular deposit may have originally formed in a glaciomarine environment during an early Devensian stadial as proposed by Sutherland (1981), but not necessarily during a period of locally elevated sea level.

\section{Geological setting and stratigraphy of the Clava sediments}

The geology and geomorphology of the Clava area has been described in detail by Merritt (1992) (also see Fletcher et al., 1996; British Geological Survey, 1997), and is, therefore, only summarised here (Fig. 1). The variably deformed glacigenic sequence at Clava underlies a series of NE-SW-trending benches (up to c. $265 \mathrm{~m}$ OD). These benches slope gently both downstream and towards the centre of the Nairn valley, with the lower ones having been modified by glacial drainage in an ice marginal setting. The glacial sequence (up to $40 \mathrm{~m}$ thick) at Clava is complex, including tills, sands and gravels and thrust-bound rafts of shelly clay, shelly diamicton and glaciofluvial sand and gravel, with two important interglacial and interstadial sites occurring nearby (see Fig. 1). The sediments rest upon bedrock of Middle Devonian sandstones and conglomerates (Inverness Sandstone Group), unconformably overlying a basement of Neoproterozoic metamorphic rocks intruded by younger granites (Fletcher et al., 1996). 
The glacial sediments are exposed in a series of sections in the valleys of the Cassie and Finglack burns (Fig. 1), but the full sequence can not be seen at any one site as it has been dissected by a number of gently dipping thrusts and 'high strain zones'. Consequently, establishing the original stratigraphical relationships between the rafted units is problematic. The stratigraphy summarised in Table 1 follows that proposed by Merritt (1992) and Fletcher et al. (1996), rather than the more formal, less widely used nomenclature of Bowen (1999). Although the validity of applying formal lithostratigraphical rules to units that are only known from tectonically bound rafts may be questioned, the main three components of the rafts, namely Clava Shelly Till, Clava Shelly Clay and Clava Sand, have been defined as members within the Clava Shelly Formation (Table 1). A newly defined fourth unit, the Clava Gravel, has been added here.

\section{Analytical techniques}

Prior to sampling the sedimentary sequences exposed in the Clava area were logged and the macro-scale characteristics of the sequence (e.g. geometry of the units, lithology, macroscopic deformation structures...etc) were described in detail. A total of six orientated samples were collected from the glacigenic sediments exposed in Cassie Burn and the top if the rafted sequence at the Clava Main Pit. Individual samples were collected using $10 \mathrm{~cm}$ square, aluminium Kubiena tins, which were either cut or pushed into the face of each exposure in order to limit sample disturbance. The geographical position, orientation relative to magnetic north, depth and way-up of the sample were marked on the outside of the tin during collection. Each sample was then removed from the face, sealed in two plastic bags, and then stored in a cold store to prevent the material from drying out prior to sample preparation.

Sample preparation (total time c. 10 months involved the initial replacement of pore-water by acetone, which was then progressively replaced by a resin and allowed to cure. The thin sections were cut orthogonal to bedding and to any deformation structures evident from field investigation. The thin sections were examined using a standard Zeiss petrological microscope and Zeiss projector, the latter allowing detailed study of the range of microstructures at very low magnification. The terminology used to describe the various microstructures developed within these 
sediments in general follows that proposed by van der Meer $(1987,1993)$ and Menzies (2000).

\section{Stratigraphical relationships and macroscopic deformation structures}

The oldest unit at Clava, the Cassie Till Formation (CTF) (Table 1), has only been proven in boreholes and is thought to be a pre-Late Devensian basal till (Merritt, 1992). This till is overlain by the Drummore Gravel Formation (DGF), a sequence of crudely stratified, very poorly sorted and clayey gravels containing pebbles and large blocks of Devonian sandstone. This gravel-rich unit ( $\leq 3 \mathrm{~m}$ thick) crops out at the base of the Finglack section [NH 7688 7422] (Fig. 2), where water-winnowed, siltrich diamicton, interpreted as an ice-marginal or supraglacial debris flow deposit (Merritt, 1992), is overlain by folded and thrusted sediments of the Clava Shelly Formation (CSF). The sharp, planar contact between the two units represents a glacitectonic décollement that developed at the base of the rafted CSF. The clay, silt and sands immediately above this thrust are similar in appearance to the upper part of the Clava Shelly Clay Member (CSCM) at the Main Pit, but are highly deformed (a glacitectonite of Benn and Evans, 1998), showing evidence of several phases of folding and faulting, as well as soft-sediment deformation (Fig. 2b). This glacitectonite is overlain by a dark grey pebbly diamicton, assigned to the Clava Shelly Till Member (CSTM), which is separated from the overlying Finglack Till Formation (FTF) by a prominent, gently SE-dipping thrust zone (Fig. 2). Individual thrust planes within this zone are marked by thin layers of hard, sheared silty clay, with the upper and lower bounding thrusts being separated by a 'high strain zone' composed of highly sheared clayey sand.

In Cassie Burn section III [NH 7637 4369] (Fig. 1), the rafted sequence is deformed by a number of thrusts that truncate bedding and earlier developed folds (Fig. 3). The Clava Shelly Till and Clava Sand (CSM) members in the lower part of the section are overlain by several metres of deformed (thrusted) sand and gravel identified as glaciofluvial ice-contact deposits by Merritt (1992), referred to here as the Clava Gravel Member (CGM) (Fig. 3; Table 1). The CGM comprises predominantly waterlain, poorly sorted, clast-supported gravel interbedded with pebbly, medium to coarse sand. The gravel clasts are mostly composed of micaceous metasandstone with subordinate semipelitic gneiss, brown sandstone and granitic 
gneiss, an apparently 'exotic' (not locally derived) suite of lithologies. The basal contact of the CGM is a gently to moderately (c. $40^{\circ}$ ) NE-dipping thrust (Fig. 3). A small splay from this thrust deforms the upper part of the structurally underlying CSM. The tip of this thrust is marked by a tight, isoclinal fold, which is itself truncated by a later reverse fault (Fig. 3c). A gently to steeply, NE-dipping “" "high strain zone", ( $\leq 50 \mathrm{~cm}$ thick) near to the base of the CGM (Figs. 3 and 4 ) is composed of highly deformed, laminated clay and silt containing lenses or boudins of sand and diamicton (CSTM).

The CSTM (Table 1) is an olive grey, stiff, fissile, matrix-supported, silty clay-rich diamicton containing clasts of micaceous metasandstone, quartzite and gneiss, with lesser amounts of granite and Devonian sandstone. Apart from the clasts of sandstone, which are generally angular, others are rounded to well-rounded, moderate to high sphericity, and polished, similar to the distinctive, exotic clast assemblage described in the CSCM at the Main Pit by Horne et al. (1894). The difference in faunal assemblages between the CSCM and CSTM, however, show that the till is not simply derived from disintegration of the glaciomarine clay during glaciation and rafting. In Cassie Burn section III, the CSTM includes a number of discrete masses of fissile, dark bluish grey clay, containing comminuted shells and sparse stones, which were 'cannibalised' from a pre-existing marine deposit. A crudely developed layering in the diamicton is deformed by a SSW-verging, NEplunging, asymmetrical fold (Fig. 3). At this location, the CSTM and structurally overlying CSM are separated by a gently dipping to subhorizontal thrust. This thrust truncates a large monoclinal fold that deforms, and locally overturns bedding within the sand (Figs. 3a and b). This relationship indicates that folding pre-dated thrusting. However, this does not necessarily imply that folding and thrusting represent completely separate deformation events. The CSM forms a thrust-bound wedge that thins rapidly to the NE where it is cut out against a thrust forming the base of the overlying CGM (Fig. 3). Soft-sediment deformation structures (flame structures, disharmonic folds, convolute bedding) are common in the finer grained, lower part of the CSM, indicative of locally high pore-water pressures/contents during deformation. Bedding in the sand unit is also locally offset by locally pervasively developed, smallscale, steeply dipping $\left(50^{\circ}-60^{\circ}\right)$, conjugate normal faults. The CSCM is apparently missing in section III, possibly having been excised during thrusting. 
In the type section of the Clava Shelly Formation at the Main Pit (Fig. 1), the rafted sequence is much thicker and, in general, less deformed. It records a relatively coherent, gently dipping, coarsening upwards sequence that extends at least $174 \mathrm{~m}$ in the NE-SW-direction (Horne et al., 1894). Borehole evidence indicates that the CSCM (4.9 m thick) rests directly upon the DGF, and comprises a sequence of weakly stratified, pebbly silt and clay (Horne et al., 1894). This clay dominated sequence also contains laminae of sand and streaks of black carbonaceous, as well as thin gravel beds with scoured bases and containing broken shells. The lamination is locally offset by small-scale normal and reverse faults, and closely spaced shears bearing slickensides.

At the Main Pit, the CSCM is conformably overlain by the CSM, the basal 3 m thick unit of which comprises thinly bedded, yellowish brown, micaceous, silty fine-grained sand with sparse dropstones. The beds are normally graded and stacked into packages about $40 \mathrm{~cm}$ thick, similar to those described in the younger Ardersier Silt Formation found towards the coast of the Moray Firth and interpreted as having been deposited in a glaciomarine fjord setting (Merritt et al., 1995). The uppermost unit (c. $3 \mathrm{~m}$ thick), comprises yellowish brown, massive to indistinctly laminated silty fine- to medium-grained sand with thin lenses of coarse-grained sand with scoured bases, and sparse dropstones. This sandy unit is cut by a number of bedding-parallel to steeply $\left(60-80^{\circ}\right)$ NE-dipping hydrofractures composed of finely laminated to brecciated sand, silt and clay (Fig. 5). Individual sand and silt laminae $(\leq 1.5 \mathrm{~cm}$ thick) within the veins are graded, some containing intraformational rip-up clasts of silt and clay. The veins ( $\leq 15 \mathrm{~cm}$ thick) can be traced laterally for several metres and most taper upwards (see Fig. 5).

Close to the top of the sequence, the bedding within the CSM is deformed by several moderately to gently inclined folds and thrusts. These deformation structures are locally truncated by the hydrofractures (Fig. 5c), indicating that folding and thrusting pre-dated the formation of these water-escape features. At the base of the overlying FTF, the CSM is very highly deformed with bedding having been variably transposed by a glacitectonic foliation. Parallel to the planar, subhorizontal base of the till is a $40 \mathrm{~cm}$ thick zone of highly deformed, overconsolidated, silty fine-grained sand containing boudinaged lenses of diamicton, stringers of coarse sand and deformed fragments of clay. The hydrofractures present in the lower parts of the CSM are 
clearly truncated by this 'high strain zone' (Figs. 5a and c). This relationship indicates that hydrofracturing occurred prior to ductile shearing.

In the Finglack Burn section (Fig. 1), the conformable relationship between the CSCM and CSM members has been strongly modified by thrusting, leading to the emplacement of CSTM onto the CSCM (Fig. 2). The thrust contact between these two units was later deformed by open, upright to weakly asymmetrical folds (Fig. 2a). The rafted sediments are cut out towards the SE, where the FTF rests directly upon the DGF (Fig. 2). This locality is the type section of the FTF, which comprises a thick (at least $8 \mathrm{~m}$ ), massive unit of yellowish brown, stiff, matrix-supported, stony diamicton with a matrix of clayey fine-grained sand. Like many tills overlying Devonian rocks in the vicinity, it contains mainly faceted and striated clasts of sandstone and micaceous siltstone, many of which can be matched with strata cropping out immediately to the $\mathrm{W}$ or SW of the site. The basal few metres of the till contains relatively abundant, well-rounded, high-sphericity and commonly polished pebbles of micaceous metasandstone. The basal contact of the till is formed by a "high strain zone’’ (Fig. 2) similar to the one present within the Main Pit section.

In Cassie Burn section VI (Fig 1), only the FTF is exposed. At this locality the basal part of the till is locally cut by a ramifying network of interconnecting to cross-cutting hydrofractures filled by finely laminated sand, silt and clay (Fig. 6). In Cassie Burn section III, the exposed FTF is relatively inaccessible and rests upon a tectonically thickened sequence of CGM (Fig. 3).

\section{Micromorphology and microscopic deformation structures}

Orientated samples (N4691; N4692; N4693; N4694; N4695; N4696) were collected to examine the range of microscopic deformation structures developed within the glacigenic sediments of Cassie Burn section III (Figs. 3 and 4) and those exposed at the top of the rafted sequence at the Main Pit (Fig. 5).

\subsection{High strain zones}

Sample N4691 was taken from the prominent 'high strain zone' near the base of the CGM in Cassie Burn section III (see Figs. 3a and 4). In thin section the zone is composed of alternating layers of variably deformed and disrupted, fine to medium sand and silt, with minor clay intercalations (Fig. 7a). Although, in outcrop, the layering within the 'high strain zone' is apparently glacitectonic, many of the sand 
and silt layers are graded (fining or coarsening upwards), indicative of deposition by water. The relationships between individual sand and silt layers are complex, suggesting that the layering is not simply sedimentary in origin. For example, in the upper part of thin section, a thick layer of laminated and graded sand and silt is crosscut by an inclined band (5-6 mm thick) of pale, matrix-poor sand, which is itself cut by a bifurcating clay-filled water-escape conduit (Fig. 7a). Elsewhere in sample N4691, the lamination within the sands is either diffuse or patchily developed/preserved, with the sediment possessing a mottled appearance, compatible with liquefaction and remobilisation (Phillips et al., 2007).

The clay-rich layers are composed of finely laminated silt and clay, with thin lenticles of cement/matrix-supported fine to coarse sand. The clay is highly birefringent (clay cutan) and possesses a well-developed layer-parallel plasmic fabric. This fabric is deformed by kink-like folds and shears, the latter defining an anastomosing network of small-scale, SE-directed thrusts. Thrusting preferentially occurred within the clay layers with the adjacent sands being little affected by this deformation. Individual sand laminae were observed locally cross-cutting the thrusts (Fig. 7). Both the thrusts and sand layers are off-set by a number of gently to moderately dipping normal and reverse faults (Fig. 7a). The sense of movement on the reverse faults, like the thrusts, is towards the SE. The faults also deform the clayfilled water-escape conduits and, therefore, post-date both thrusting and hydrofracturing.

\subsection{Clava Shelly Till Member}

In thin section (N4692) the Clava Shelly Till Member is a massive, fine-grained, matrix-supported, diamicton with a fine silty clay matrix containing well-dispersed granule to pebble-sized metamorphic and granitic rock fragments Rare shell fragments (gastropod) and sparse till pebbles are also present. The larger clasts are enclosed within an envelope or coating of clay which locally possesses a welldeveloped skelsepic plasmic fabric. Two generations of planar plasmic fabrics have been recognised within the matrix of the till: (i) a weakly to moderately developed, layer-parallel foliation defined by optically aligned clay plasma and detrital micas; and (ii) a second, steeply inclined (unistrial) fabric defining a number of narrow shears. The shears have poorly defined margins and post-date the main, layer-parallel

foliation. Rare circular to arcuate grain arrangements (rotational structures) are 
present enclosing larger granules and pebbles. No other microscopic deformation structures (folds, faults) have been noted.

\subsection{Hydrofractures}

Hydrofractures are a relatively common feature within the sequence exposed at Clava, occurring within both the CSM and FTF. No samples were obtained from the FTF due to the highly overconsolidated nature of this subglacial diamicton. Four orientated samples (N4693; N4694; N4695; N4696) were, however, taken from a laterally extensive hydrofracture system cutting the CSM exposed in the Main Pit. Field evidence shows that this hydrofracture system truncates the earlier developed folds and thrusts, but is itself truncated by the 'high strain zone' at the base of the overlying FTF. Samples N4693, N4694 and N4695 represent the layer-parallel section of this system (Fig. 5b), whereas sample N4696 occurs at a structurally higher position within the steeply inclined portion of the hydrofracture system (Fig 5c; also see Fig. 10).

The thin sections are all composed of variably deformed, laminated sand, silt and clay (Figs. 7b, 8a and 8b), which represent a combination of the host CSM and fluidised sediment injected into the hydrofracture system. The clay-rich layers are composed of finely laminated silt and clay, with thin lenticles and irregular patches of coarse to medium, matrix-supported sand (CS1 on Figs. 7b, 8b and 9). The thicker clay-silt laminae are graded (fining upwards) and possess a well-developed beddingparallel plasmic fabric. Both the lamination and plasmic fabric are deformed by an anastomosing network of bedding-parallel to gently dipping thrusts, and at least one set of normal and reverse microfaults (Figs. 7b and 8a). Thrusting preferentially occurred within the clay layers. However, the adjacent sands showing little evidence of this deformation and locally cross-cut and, therefore, post-date the thrusts. In samples N4695 and N4696, thrusting was accompanied by localised disharmonic folding and brecciation of the clay layers (Figs. 8b and 9). The brecciated layers comprise angular, randomly orientated fragments of silt and clay within a matrix of cement-supported sand and silt. The brecciated layers are cut by more massive sands (e.g. SS1 and SS3 on Fig. 8b) that are unaffected by this brittle deformation. However, in samples N4693 and N4694, the equivalent sands are cut by a layerparallel to locally transgressive water-escape feature filled by a lithologically similar clay-rich microbreccia (MB on Figs. 7b, 8a and 10). 
The layers of fine to coarse sand are massive to weakly laminated with a variably developed normal (fining upwards) or reverse (coarsening upwards) grading. The margins of the sand layers are sharp, ranging from planar, to locally irregular, 'sutured', or even flame-like. A number of the thicker sands clearly truncate the lamination and thrusts developed within the adjacent silts and clays (see Figs. 7b, 8a and 8b); consistent with the liquefaction, remobilisation and injection of the coarser grained sediments. In general, the sands are undeformed. However, in sample N4694 the margins of some sand layers are modified by thrusting and are locally offset by a set of later normal and reverse faults (Fig. 8a).

The lower right-hand of sample N4693 is cut by a 20 to $30 \mathrm{~mm}$ wide, NEdipping $\left(40-50^{\circ}\right)$ water-escape conduit filled by cross-cutting fills of massive to weakly laminated sand (F2 on Figs. 7b and 10). This feature is correlated with a more shallowly $\left(5-10^{\circ}\right)$ dipping conduit present in the upper part of sample N4694 (F2 on Figs. 8a and 10). Later, vein-like hydrofractures composed of laminated fine sand, silt and clay (LV1 and LV2 on Figs. 7b, 8a and 10) truncate the earlier sand-dominated fill. These relationships are consistent with the water-escape conduit having accommodated several phases of fluid flow.

Samples N4693 and N4695 are both cut by steeply $\left(70-80^{\circ}\right)$ inclined hydrofractures that clearly truncate the layering within the host sediments, as well as an earlier sand-filled water-escape conduit (see Fig. 10). In both samples, the later hydrofractures possess multiple generations of sediment fill (Table 2). The earliest fill is a microbreccia composed of angular, variably deformed fragments of clay and silt in a silty sand matrix (HF1 on Figs. 7b and 8b). This microbreccia is cut by a complex vein-like network of sand and highly birefringent clay (HF2 on Figs. 7b and 8a, Table 2). In sample N9463, the earlier fills are cut by a vein of highly birefringent, redbrown clay (HF3 on Fig. 7b, Table 2). In marked contrast to this clay-rich fill, in sample N4695, the final flow event resulted in the deposition of weakly laminated to massive sand (SS7 on Fig. 8b, Table 2). This sand-fill is connected to a lithologically similar sand layer present at the bottom of the thin section (Fig. 8b).

In the subvertical part of the hydrofracture system, represented by sample N4696, the hydrofracture is funnel-shaped (widening upwards) and comprises a multiphase fill of clay, silt and sand (Figs. 9 and 10, Table 2). Unlike the layerparallel part of the hydrofracture system (represented by samples N4693, N4694 and 
N4695), this near vertical section is associated with locally intense brecciation of the adjacent sediments. Fragmentation was accompanied the injection of irregular patches and veinlets of coarse sand (CS1, CS2 and CS3 on Fig. 9). The distribution pattern of the coarse sand fills suggests that the pressurised fluidised sand 'radiate outward' (upwards) from a central conduit (see Fig. 10). The normal microfaults in the sediment wall of the hydrofracture downthrow towards the centre of the conduit (Fig 9). It is likely that faulting occurred in response to the collapse within this funnelshaped hydrofracture system after fluid flow had ceased. The main part of the conduit is filled by a complex network of sand, silt and clay veins (HF1, HF2 and HF3 on Fig. 9). A diffuse, poorly preserved lamination within the sand (HF1) is deformed by a number of rootless disharmonic folds. The later silt- and clay-rich fills (HF2 and HF3) form a cross-cutting, vein-like network. A well-developed plasmic fabric within the clay-rich fill occurs parallel to the margins of the hydrofracture and probably formed in response to the adhering of the clay plasma to the margins of the fracture. The earlier fills are cut by small, patches or veins of sand (SS7 on Fig. 9).

\section{Macroscopic structural interpretation}

The relative positions and major structures developed within the glacigenic sequences exposed within the Finglack Burn, Clava Main Pit and Cassie Burn sections are shown in Fig. 11 (also see Fig. 12a). the overall geometry of the main thrusts and 'high strain zones' developed within these polydeformed sediments is consistent with the rafts of Clava Shelly Formation forming a lenticular duplex-like structure which formed adjacent to a bedrock high located on the SE side of the Nairn river valley. This assemblage of rafts occurs within an envelope that is in the order of $900 \mathrm{~m}$ long by $300 \mathrm{~m}$ wide (Fig. 12), and a few tens of metres thick.

The major bounding structures of the duplex are formed by the 'high strain zones' which dissect the Clava succession. On Fig. 11 these shear zones divide the Clava Shelly Formation into two discrete rafts; a structurally lower raft composed of the polydeformed CSCM, CSTM and CSM, with the higher raft being solely composed of the variably deformed (thrusted) sands and gravels of the CGM. The upper bounding surface of the duplex is formed by the prominent 'high strain zone' at the base of the Finglack Till Formation (Fig. 11). The basal décollement surface separating the Clava Shelly Formation from the underlying Drummore Gravel Formation can be seen in the Finglack Burn section. This section occurs close to the 
'tip' of the duplex (see Fig. 11) with the sediments recording the most intense deformation, leading to the formation of a polydeformed glacitectonite from the CSCM.

The upper raft at Clava is exposed within Cassie Burn section III and thins towards the SE, where it maybe pinched out by the merging of two highs train zones (Fig. 11). The basal detachment to this raft is formed by the gently to steeply, NE-dipping "'high strain zone”' which occurs near to the base of the CGM (Figs. 3, 4 and 11). The sequences exposed within the Clava main Pit and lower part of Cassie Burn section III occur towards the centre of the structurally lower raft (Figs 11 and 12a). although less deformed, leading to the local preservation of original stratigraphical relationships, these sediments have clearly undergone several phases of folding and thrusting. This does not necessarily imply that folding and thrusting represent completely separate deformation events. The southerly verging folds which deform the stratification/bedding within the CSTM and CSM are truncated by a number of later, subhorizontal to moderately northerly-dipping thrusts (Figs 3 and 11). These SEdirected brittle structures form the boundaries between slices of CSTM, CSM and CGF, overprinting the original stratigraphical relationships between these units and leading to the imbrication/stacking of the sediments within the lower raft. The thrusts are sharp, planar features, lacking the apparently intense zone of ductile shearing which characterise the main bounding surfaces of the duplex. The thrusts are locally folded (e.g. Finglack Burn Cassie Burn section III, Fig. 11) recording further compression/shortening, possibly associated with the transport of the rafts. In Finglack Burn and upper part of the Main Pit section, the folds and thrusts which deform the Clava Shelly Formation are truncated by the 'high strain zones' which form the bounding surfaces of the raft (Figs. 2 and 11). These relationships indicate that folding and thrusting predated the main phase of ductile movement along the 'high strain zones'. It is possible that this early folding and thrusting event occurred during either the initial detachment of the rafts or during the earlier part of their transport history.

Hydrofracturing is locally a common feature both within the ice-rafted Clava Shelly Formation and structurally overlying Finglack Till Formation. In the Main Pit, the bedding-parallel to steeply NE-dipping Hydrofractures clearly cross-cut the early developed folds and thrusts present within the CSM, demonstrating that water-escape post-dated folding and thrusting (Fig. 5). The Hydrofractures are, however, truncated 
by the 'high strain zone' at the base of the FTF (Figs. 5a and c), showing that is phase of water-escape occurred prior to ductile shearing at the base of the till. In the Cassie Burn section VI, the lower part of the FTF is cut by a network of sand-filled Hydrofractures (Fig. 6), possibly recording a separate phase of water-escape which post-dated the deposition of the till. These complex relationships are interpreted as recording several phases of Hydrofracturing and water-escape during rafting. The earliest phase occurred after initial folding of the Clava succession, but prior to al least the later phases of ductile shearing along the upper boundary of the duplex. The later phase of water-escape apparently post-dated this shear event and affected the lower parts of the Finglack Till Formation. This latter phase of water-escape possibly occurred during the later stages of accretion of the rafts as the glacier overrode the topographic high formed by the SE side of the Nairn river valley.

\section{Micromorphological evidence of multiphase liquefaction and water-escape during deformation}

It is clear from the above description that liquefaction, remobilisation and injection of the sand, silt and, to a lesser extent, clay played an important role during the deformation of the glacigenic sedimentary sequence exposed at Clava.

\subsection{High strain zones}

The influence of relatively high pore-water contents and/or pressures was not confined to the formation of hydrofractures, but has also been recognised within the 'high strain zones' that dissect the Clava succession. These zones represent major décollement surfaces, cutting out and repeating parts of the succession (see Figs. 2, 3 and 11). Although field observations suggest that these structures possess a welldeveloped glacitectonic foliation, micromorphological analysis (N4691) has revealed that the intensity of deformation recorded by these zones is much lower than expected. Importantly, the range of microtextures present within one of the 'high strain zones' is similar to those developed within the hydrofracture system sampled from the Main Pit (compare Fig. 7a with Figs. 7b to 10). The absence of deformation and presence of normal and reverse grading within the locally cross-cutting sand layers indicates that, rather than being tectonic, the fine-scale layering within the 'high strain zones' was (at least in part) formed by the injection of fluidised sediment parallel to the margins of these structures. Deformation, where present, was relatively 
early and dominated by thrusting, within the clay-rich layers (Fig. 7a). The presence of clay-filled water-escape features (hydrofractures) provides further evidence that the 'high strain zones' periodically acted as a focus for subsequent fluid flow. Repeated phases of liquefaction and remobilisation in response to fluctuating pore-water content and/or pressure would have resulted in the overprinting of any earlier formed thrusts or folds.

The periodic introduction of pressurised fluidised sediment into the 'high strain zones' would have resulted in a reduction in the shear strength of the sediments, therefore, aiding displacement. The increase in pore-water pressure during injection of the fluidised material into the shear zone could have acted as a 'hydrogeological jack', resulting in the effective decoupling of the margins of the rafts from the surrounding sediments. One significant effect of this decoupling would have been to increase the preservation potential of the soft-sediment rafts during an extended period of transport. The fluctuation in fluid flow, possibly reflecting a seasonal variation in melt water production, would have led to a 'stick-slip' pattern of movement. The presence of water lubricated detachments within the deforming bed of the glacier would have assisted in the transportation of the raft from its source (see discussion). Shear imposed by the overriding glacier would have been preferentially partitioned into these water lubricated décollement surfaces, effectively 'switching off' deformation in the adjacent hanging wall and footwall. This would have contributed to the preservation of primary stratigraphical relationships within the thicker parts of the ice rafted sequence (Main Pit), concentrating deformation along the margins of the raft.

\subsection{Hydrofractures}

Hydrofractures are a relatively common feature at Clava. Field relationships indicate that hydrofracturing of the CSM post-dated folding and thrusting, but predated shearing at the base of the overlying FTM. The locally ramifying network of hydrofractures developed within the till, however, shows that hydrofracturing and water-escape continued after ductile shearing and till deposition had ceased.

Micromorphological evidence from one hydrofracture system within the CSM shows that these structures do not represent a single 'flow event', but have accommodated several phases/pulses of water-escape. The cross-cutting relationships displayed between the various generations of sand, silt and clay-fills, and their relationship to the folds and thrusts developed within the host sediments has enabled a 
detailed chronology of events to be erected for each sample (Table 2). The key relationships between the various generations of sediment fill are shown in Fig. 10. The complex history of liquefaction and deformation recorded within the hydrofracture system can be simplified into four main events:

Event I - An early phase of layer-parallel thrusting with associated folding and ductile shearing which was preferentially partitioned into the laminated clay-rich host sediments (see Fig. 10);

Event II - Repeated injection of fluidised sediment parallel to bedding/layering in the host sands, resulting in the formation of a relatively wide zone of fluid flow. This injection was accompanied by minor thrusting and/or faulting;

Event III - Development of broad water-escape conduits (e.g. F2 on Fig. 10) cross-cutting the earlier developed layering and possibly recording the concentration of fluid flow into narrow zones within the overall hydrofracture system;

Event IV - Late stage hydrofracturing with sand, silt and clay-filled hydrofractures cross-cutting the earlier formed features (e.g. HF2/3, LV1 and LV2 on Fig. 10).

Microstructural analysis supports the macroscopic field evidence that the main phase of thrusting and folding within the CSM predated hydrofracturing and waterescape. However, in thin section (N4695), the thrusting was accompanied locally by disharmonic folding and brecciation. The brecciated areas are cut by small-scale, siltfilled water-escape conduits and patches of coarse matrix-supported sand. These relationships suggest that even at an early stage of the deformation history, the sediments at Clava where undergoing localised liquefaction and remobilisation.

Thrusting was followed by the repeated injection of thin layers or laminae of fluidised sand parallel to bedding in the host sediments (Event II, Table 2). Earlier formed thrusts may, in some cases, have formed the focus for fluid flow during this phase of water-escape. The margins of the subhorizontal part of the hydrofracture system are difficult to define, suggesting that this zone of fluid flow may have initially been rather diffuse. The laminated and graded nature of individual sand layers indicates that the flow regime changed during deposition, reflecting fluctuations in pore-water pressure. Individual 'flow events' may have commenced with the injection of highly pressurised water/fluidised sediment leading to the initial 'opening' of a conduit within the hydrofracture system. As pore-water pressure decreased the velocity of the water flow would have waned leading to the deposition 
of the graded sediment fill, therefore, sealing the conduit. The observed cross-cutting relationships between individual sand layers indicate that the injection of each pulse of fluidised sand was followed by a fall in relative pore-water pressure. This suggests that water was able to drain out of the sediments and, consequently, it is unlikely that high pore-water pressures were continually maintained during deformation. The frequency of the individual 'flow events' may have shown larger-scale variation in response to seasonal fluctuations in melt water production (i.e. the hydrofracture system would have been more 'active' during the summer).

As deformation continued, fluid flow appears to have been concentrated into narrower zones within the overall hydrofracture system, leading to the injection of discrete, layer-parallel to transgressive sand-filled water-escape conduits (Event III, Table 2). These internally complex features accommodated several phases of fluid flow and sediment fills (see Figs. 7b, 8a and 10, Table 2). The margins of these veinlike structures are sharp suggesting that pore-water pressure/content in the sand had fallen prior to veining, hence, allowing the propagation of an 'open' fracture through originally liquefied sand.

The final event (Event IV, Table 2) resulted in the development of steeply inclined hydrofractures (Figs. 7b, 8b, 9) which truncate all the deformation and waterescape features. Once again, hydrofracture developed during Event IV records a multiphase history of fluid flow and comprise a complex sequence of cross-cutting sand, silt and clay fills (Figs. 8b, 9 and 10, Table 2). Although the samples were collected from different structural positions along the main hydrofracture system, the similarity in morphology and composition of the fills suggests that they developed during the same event. The earliest phases of fill are only locally preserved. In sample N4696, the early coarse sand fills (CS1, CS2, CS3 on Fig. 9) are absent in the lower part of the hydrofracture (see Fig. 10). This may be due to a lack of sediment deposition in this part of the fracture or, alternatively, the 'flushing out' of the early sandy fills during a subsequent phase of fluid flow. The over pressurised nature of the escaping water-sediment-mix resulted in the localised brecciation of the host sediments (Figs. 7b and 9), as well as disharmonic folding and minor drag folding of earlier fills and adjacent sediment wall (Figs. 8b and 9) due to the force/shear exerted by the escaping water/liquefied sediment. Normal faulting within the wall of the hydrofracture (e.g. N4696) probably occurred in response to the collapse of this funnel-shaped conduit after flow had ceased. The combination of brecciated walls and 
evacuation of sediment filling the conduit during a subsequent flow event would have led to this instability and collapse. The introduction of clay-rich sediment fills (Figs. 7b and 9) would have helped stabilise the walls of the hydrofracture system. The adhering of clay plasma to the margins of the fracture, leading to the development of a well-developed plasmic fabric, would have armoured the adjacent sediments protecting them from erosion and effectively 'cementing' the fracture walls.

\section{Original depositional setting of the rafted sediments at Clava}

Merritt (1992) concluded that the composition and upwards-increasing grain size of the sediments exposed within the Main Pit at Clava, together with decreasing salinity inferred from the dinoflagellate cysts within the CSCM (Graham et al., 1992), suggests that the original sequence records the encroachment of a delta or subaqueous fan into the Loch Ness basin, then a marine fjord. The faunal assemblage within the CSCM and available dating evidence suggests that deposition followed a period of glacial retreat and lowering of local sea level within a mid-Devensian interstadial.

The composition of the CGM (Cassie Burn section III), which forms the upper raft recognised at Clava (see Fig. 11) closely matches stones found within the structurally underlying CSTM and CSCM (Merritt, 19992). A significant proportion of the gravel (c. 9 modal \%) comprises a granitic gneiss that is lithologically similar to rocks exposed in the Glen Moriston/Fort Augustus area at the SW end of Loch Ness, some $50 \mathrm{~km}$ to the SW of Clava. The CGM is, therefore, thought to have formed the uppermost unit of the coarsening-upward sequence as it prograded into the Loch Ness basin. The distance between the site of deposition of the CGM and remainder of the Clava Shelly Formation within the Great Glen, to the site of accretion of these allochthonous rafts at Clava indicates a minimum distance of tectonic transport of c. $50 \mathrm{~km}$. The possible path taken by these rafts, based upon the regional pattern of ice movement, is shown in Fig. 12.

Sissons (1967) claimed that an erratic of supposed Jurassic rock in the CSCM indicated that the material had been transported southwards from the Moray Firth (by a glacier flowing out of the Beauly Firth). However, there is no corroborating evidence in support of this model. The Beauly Glacier was involved in a late-stage readvance in the Inverness district (Ardersier Readvance), depositing indicator erratics of the distinctive 'Inchbae' granitic gneiss (Merritt et al., 1995). However, 
none of these erratics have been reported from the succession at Clava, or surrounding area.

\section{Discussion: glacitectonic model for rafting at Clava}

The dimensions and general subhorizontal aspect of the assemblage of rafts exposed at Clava, coupled with the associated thrusting and large-scale folding of these bodies, are typical of many glacially-transported rafts described in the literature (see Stalker, 1976; Moran et al., 1980; Bluemle and Clayton, 1984; Aber, 1985, 1988; Ruszczynska-Szenajch, 1987; Broster and Seaman, 1991; Benn and Evans, 1998). In North America, large-scale rafts, 'megablocks' or 'pancake rocks' occur within areas of glacial-thrust terrain (Moran et al., 1980), with the thrusted rafts of bedrock having been transported near to the base, or in front of the advancing glacier (referred to as glacitectonic rafts by Ruszczynska-Szenajch, 1987). The degree of internal deformation within these rafts is thought to be dependant upon their competence relative to that of the enclosing material (e.g. ice) and to the distance travelled. Aber (1985) concluded that unless soft sedimentary rafts remain deeply frozen they will be distorted and ultimately loose their identity due to subglacial shearing and/or proglacial deformation. These frozen rafts, therefore, should only survive transport for a limited duration as they are liable to thaw, break apart and homogenise during transportation.

At Clava, however, there is no clear evidence that the rafts of shelly glaciomarine sediments were frozen at any time during their history of entrainment, transport and final accretion/deposition. Rather, both macro- and microscopic evidence indicates that liquefaction, hydrofracturing and water-escape occurred repeatedly during deformation of the sequence, recording the fluctuation pore-water pressure/content during rafting. This evidence, coupled with the presence of largescale detachments within the sequence, has resulted the development of a purely glacitectonic model for the rafting and emplacement of the marine sediments at Clava (Fig. 13).

\subsection{Initial detachment of the rafts}

The ice rafted sequence at Clava is thought to have originally been deposited by a delta or subaqueous fan as it prograded into the Loch Ness basin, which was a marine fjord at the time. Macroscopic field evidence and microstructural analysis 
reveal that the earliest phase of deformation (Event I, Table 20 recorded by these sediments resulted in folding, followed by thrusting. This sequence is thought to record a progression from the onset of ice-push (folding) as the outlet glacier commenced its advance NE-ward along the Great Glen, through to further shortening of the sedimentary pile (thrusting) as the ice continued to impinge and override this deltaic sequence (Figs 12 and 13). Initial detachment of the rafts of Clava Shelly Formation is thought to have occurred during this thrusting event, probably in a submarginal to immediately proglacial setting (Fig. 13). Thrusting appears to effected the whole of the sediment pile within the fjord resulting in the incorporation of the underlying glaciomarine sediments into the thrust stack, these later becoming deformed into the CSTM. The detached sediment slabs were subsequently completely over-ridden as the glacier continued to advance NE along the Great Glen.

Moran (1971), Banham (1975) and Moran et al. (1980) have argued that the combination of high pore-water pressures and interlayered permeable and impermeable strata provide optimal conditions for the detachment of rafts. Merritt (1992) suggested that drainage in front of the advancing Great Glen Glacier may have been impeded by the presence of the outlet glacier flowing out of the Beauly Firth (Merritt, 1992, fig. 7). This restricted drainage would have assisted in the development of high pore-water contents within the deforming sediments. Furthermore, the subaqueous depositional setting of the Clava Shelly Formation may have attributed to the water-saturated nature of the sediments at the time of deformation. The migration of pore-water through the formation would have been retarded by the presence of impermeable layers, such as the CSCM and CSTM, allowing the build up of pore-water pressures. However, macroscopic field and micromorphological evidence clearly demonstrated that Hydrofracturing, liquefaction and water-escape did not occur until a much later stage in the deformation history (Events 2 to 4, Table 2) recorded at Clava. Consequently, thrusting of the sediment pile, which occurred early in the deformation sequence, is more likely to have resulted in the initial detachment of the rafts. A proglacial to ice marginal setting for this thrusting event would have allowed the sediments to dewater, maintaining a relatively low pore-water pressure during the early states of deformation and initial detachment.

\subsection{Transport of the ice-rafted sediments}


The rafts at Clava have been transported some $50 \mathrm{~km}$ from their site of deposition within the Great Glen prior to their eventual accretion on the SE side of the Nairn river Valley (Fig. 12). This arcuate transport trajectory developed in response to the Great Glen glacier being deflected eastwards by a more powerful outlet glacier flowing out of the Beauly Firth (Merritt, 1992). The overall effect was to force the Great Glen ice to climb out of the glen, transporting the soft-sediment rafts over the higher ground of Drumnossie Muir to the south and east (Fig. 12).

One a raft has become detached many of the published models suggest that it is transported by incorporation into the base of a glacier (Clayton and Moran, 1974; Bluemle and Clayton, 1984). This requires a compressive flow regime within the glacier, leading to an upward component of motion allowing the rafts to be sheared into the base of the ice as a result of the decreased effective stress caused by elevated pore-water pressure (Bluemle and Clayton, 1984). At Clava, however, there is no direct evidence for the rafts having been included into the base of the advancing Great Glen glacier. In fact the rafted sediments all occur structurally below the subglacial FTF with was deposited below the Great Glen glacier as it expanded SE across the Clava area (see Fig. 12c). Consequently, an alternative glacitectonic transport model is offered in which the thrusts and related 'high strain zones' that form the margins to the envelope of rafts continued to accommodate displacement during transport. The occurrence of thrust-bound slivers of CSTM within the structurally lower rafts at Clava (Fig. 11), further suggests that the transport phase of rafting occurred in a subglacial to sub-marginal setting (Fig. 13).

Although soft-sediment deformation, hydrofracturing and liquefaction can occur in both subglacially and proglacially deformed sequences (Rijsdijk et al., 1999; Baroni and Fasano, 2006), work by Phillips et al. (2007) suggests that structures equated with high pore-water pressures and contents may be more widely/pervasively developed in subglacially deformed sediments. At Clava folding and thrusting, which led to initial detachment of the rafts, were followed by several phases of liquefaction and water-escape, and the formation of a locally complex network of sediment-filled hydrofractures (Events 2 to 4, Table 2). These fluidisation events accompanied continued movement along the 'high strain zones' which form the major bounding structures to the rafts (see Fig. 11). Micromorphological evidence indicates that these structures acted as a focus for water-escape (inset Fig. 13) which led to the repeated injection of fluidised sand and silt into these actively deforming structures. This 
concentration of fluid flow along the margins of the rafts may have been assisted by the relatively clayey to silty nature of some of the sediments within the Clava Shelly Formation (such as the CSCM and CSTM). However, the occurrence of complex hydrofracture systems within the CSM, with their multiple sediment fills (Fig. 10), indicates that pore-water pressure within the rafts repeatedly exceeded the cohesive strength of these sediments. It is possible that these complex, apparently 'long lived' systems were partially fed by pore-water introduced from outside the raft (inset Fig. 13). Elevated pore-water pressures within the CSM may have been generated either in response to the tectonic thickening of the sedimentary pile and/or the increased confining pressure exerted by the overriding Great Glen glacier.

The periodic introduction of pressurised fluidised sediment along the 'high strain zones' would have led to a reduction in the shear strength of the sediment pile, aiding displacement of the rafts, and effectively decoupling these soft-sediment slabs from the surrounding host sediments. Any shear induced by the overriding glacier would have been partitioned into the 'high strain zones', concentrating deformation along the margins of the rafts and essentially 'switching off' deformation within these bodies. This would lead to an increase in the preservation potential of the softsediments rafts during transport. The decoupling of the rafts from the remainder of the glacier bed would have allowed these soft-sediment slabs to be propelled forwards encased within a thin, periodically highly mobile (dilated), water lubricated envelope; analogous to the effect achieved by trying to squeeze an orange or lemon pip between your thumb and forefinger. Fluctuations in fluid flow, possibly in response to seasonal variations in melt water production, would have led to a 'stick-slip' pattern of movement along these detachment surfaces during transport. A fall in pore-water pressure probably accompanied renewed deformation of the sediments within then raft, possibly accounting for the locally developed conjugate normal and reverse faults, and localised folding of earlier developed thrusts within the lower of the two rafts exposed at Clava (see Fig. 11).

\subsection{Emplacement or accretion of the rafts}

Emplacement or accretion of the rafts at Clava occurred on the up-glacier side of a rise in bedrock topography on the SE side of the Nairn valley. This feature corresponds with a major change in bedrock geology from Devonian Inverness Sandstone Group , in the NW, to much less permeable Neoproterozoic metamorphic 
rocks intruded by granites to the SE (Fletcher et al., 1996; British Geological Survey, 1997). This variation in bedrock geology would have probably resulted in a marked change in subglacial hydrogeology. In contrast to the impermeable upland areas to the SE of the Nairn valley, the low-lying Loch Ness and Inner Moray Firth basins were potentially situated close to sea-level and developed upon permeable sandstone bedrock, allowing long-lived wet conditions to prevail. The rafts were accreted against the bedrock high as a result of the Great Glen glacier being forced SE-ward by ice issuing from the Beauly Firth (Fig. 12c) (cf. Horne et al., 1894; Merritt, 1992). This emplacement direction is consistent with the sense of displacement (to the SE) recorded by the thrusts and related 'high strain zones' which deform the Clava sequence. Accretion of the duplex-like, thrust-bound assemblage of rafts (Figs. 11 and 13) would have aided in the Great Glen glacier overcoming the bedrock high. The accretion process was, therefore, predominantly glacitectonic and probably accompanied deposition and penecontemporaneous shearing of the basal part of the FTF (Fig. 11).

Merritt (1992) concluded that emplacement occurred whilst the Clava site was temporarily situated within the marginal, cold-based zone of the expanding LateDevensian Scottish ice sheet. Shortly afterwards, as the ice advanced NE-wards, warm-based conditions prevailed, allowing subglacial shearing and subsequent basal sliding (cf. Moran et al., 1980). However, there is no evidence that the rafted sediments at Clava were frozen during their emplacement, most of the evidence indicating conversely that the sediments were wet with hydrofracturing and waterescape also occurring within the FTF.

\section{Conclusions}

The shelly glaciomarine and related sediments exposed at Clava, NE Scotland occur in a series of thrust-bound rafts which were accreted next to a bedrock high on the SE side of the valley of the River Nairn. These sediments are thought to have originally formed a coarsening upwards sequence deposited by a delta or subaqueous fan which prograded into the Loch Ness marine basin. The distance between the site of deposition of the Clava Shelly Formation within the Great Glen, to the site of accretion of the allochthonous rafts at Clava yields a minimum estimate of tectonic transport of c. $50 \mathrm{~km}$. The geometry of the rafted sediments at Clava, coupled with the associated thrusting and large-scale folding of these bodies, are typical of many 
glacially-transported rafts described in the literature. At Clava, however, there is no evidence that the ice-rafted sediments were frozen at any time during their history of entrainment, transport and final accretion/deposition. Rather, both macro- and microscopic evidence indicates that liquefaction, hydrofracturing and water-escape occurred repeatedly during deformation. This evidence, coupled with the presence of water-lubricated, large-scale detachments within the sequence, has led to the development of a purely glacitectonic model for rafting at Clava. This model consists of an early phase of folding and thrusting in response initial shortening and overriding of the sediment pile by ice issuing from the Great Glen. This was followed by several phases of liquefaction and water-escape. Liquefaction appears to have been accompanied by continued movement along the thrusts. These thrusts and 'high strain zone's acted as a focus for water-escape with the repeated injection of fluidised sediment along these structures lubricating these décollement surfaces and aiding transport of the rafts.

\section{Acknowledgements}

This work forms part of the Engineering Geology of Tills project of the Physical Hazards Programme of the British Geological Survey. Jon Lee, Nick Golledge and Helen Reeves are thanked for their comments on an earlier draft of this manuscript. David Oates is acknowledged for his expertise in making the thin sections. Dave Roberts and Jaap van der Meer are thanked for their very constructive reviews. We would also like to thank you Mrs R. Rose of Nairnside Trust for allowing access to the Clava sites. This paper is published with the permission of the Executive Director of the British Geological Survey (NERC).

\section{References}

Aber, J.S. 1985. The character of glaciotectonism. Geologie en Mijnbouw 64, 389395.

Aber, J.S. 1988. Spectrum of constructional glaciotectonic landforms. In Goldthwait, R.P., Matsch, C.L. (Eds). Genetic Classification of Glacigenic Deposits. Balkema, Rotterdam, 281-292.

Auton, C.A., Firth, C.R., Merritt, J.W. (Eds). 1990. Beauly to Nairn: Field Guide. Quaternary Research Association, Cambridge, pp 149. 
Banham, P.H. 1975. Glacitectonic structures: a general discussion with particular reference to the contorted drift of Norfolk. In Wright, A.E., Moseley, F. (Eds). Ice Ages: Ancient and Modern. Seel House Press, Liverpool, 69-94.

Baroni, C., Fasano, F. 2006. Micromorphological evidence of warm-based glacier deposition from the Ricker Hills Tillite (Victoria Land, Antarctica). Quaternary Science Reviews 25, 976-992.

Benn, D.I., Evans, D.J.A. 1998. Glaciers and Glaciation. Arnold, London, pp 734.

Bluemle, J.P., Clayton, L. 1984. Large-scale glacial thrusting and related processes in North Dakota. Boreas 13, 279-299.

Boulton, G.S., Caban, P. 1995. Groundwater flow beneath ice sheets, Part II. Its impact on glacier tectonic structures and moraine formation. Quaternary Science Reviews 14, 563-587.

Boulton, G.S., Dent, D.L., Morris, E.M. 1974. Subglacial shearing and crushing, and the role of water pressures in tills from south-east Iceland. Geografiska Annaler 56A, 135-145.

Boulton, G.S., Dobbie, K.E., Zatsepin, S. 2001. Sediment deformation beneath glaciers and its coupling to the subglacial hydraulic system. Quaternary International 86, 3-28.

Bowen, D.Q. (Ed) 1999. A revised correlation of Quaternary deposits in the British Isles. Geological Society Special Report 23, pp 174.

British Geological Survey. 1997. Fortrose. Scotland Sheet 84W. Solid and Drift Geology. 1:50,000. British Geological Survey, Keyworth, Nottingham.

Broster, B.E., Seaman, A.A. 1991. Glacigenic rafting of weathered granite: Charlie Lake, New Brunswick. Canadian Journal of Earth Sciences 28, 649-654.

Carr, S. 2001. Micromorphological criteria for discriminating subglacial and glaciomarine sediments: evidence from a contemporary tidewater glacier, Spitsbergen. Quaternary International 86, 71-81.

Carr, S., Haflidason, H., Sejrup, H.P. 2000. Micromorphological evidence supporting late Weichselian glaciation of the northern North Sea. Boreas 29, 315-328.

Carr, S., Holmes, R., van der Meer, J.J.M., Rose, J. 2006. The last glacial maximum in the North Sea basin: micromorphological evidence of extensive glaciation. Journal of Quaternary Science 21, 131-153.

Clayton, L., Moran, S.R. 1974. A glacial process-form model. In Coates, D.R. (Ed). Glacial Geomorphology. State University of New York, Binghamton, 89-119. 
Christiansen, E.A., Whitaker, S.H. 1976. Glacial thrusting of drift and bedrock. In Legget, R.F. (Ed). Glacial till: An interdisciplinary study. Royal Society of Canada Special Publication 12, 121-130.

Fletcher, T.P., Auton, C.A., Highton, A.J., Merritt, J.W., Robertson, S., Rollin, K.E. 1996. Geology of Fortrose and eastern Inverness district. Memoir for 1:50 000 Geological Sheet 84W (Scotland). HMSO, London.

Fraser, J. 1883. First notice of a post-Tertiary shell-bed at Clava in Nairnshire, indicating an artic climate and a sea-bed at a height of 500 feet. Transactions of the Edinburgh Geological Society 4, 136-142.

Gordon, J.E. 1993. Clava. In Gordon, J.E., Sutherland, D.G. (Eds). Quaternary of Scotland: Geological Conservation Review. Chapman and Hall, London, 165-170.

Graham, D.K., Harland, R., Hine, N., Robinson, J.E., Wilkinson, I.P. 1992. The biostratigraphy of the Clava shelly clay and till. Appendix 1 of Merritt, J.W. 1992. The high-level marine shell-bearing deposits of Clava, Inverness-shire, and their origin as glacial rafts. Quaternary Science Reviews 11, 776-779.

Hart, J.K., Roberts, D.H. 1994. Criteria to distinguish between glaciotectonic and glaciomarine sedimentation: I - Deformation style and sedimentology. Sedimentary Geology 91, 191-213.

Hart, J., Rose, J. 2001. Approaches to the study of glacier bed deformation. Quaternary International 86, 45-58.

Hiemstra, J.F., van der Meer, J.J.M. 1997. Pore-water controlled grain fracturing as an indicator for subglacial shearing in tills. Journal of Glaciology 43, 446-454.

Hiemstra, J.F., Rijsdijk, K.F. 2003. Observing artificially induced strain: implications for subglacial deformation. Journal of Quaternary Science 18, 373-383.

Horne, J., Robertson, D., Jamieson, T.F., Fraser, J., Kendall, P.F., Bell, D. 1894. The character of the high-level shell-bearing deposits at Clava, Chapelhall and other localities. Report of the British Association for the Advancement of Science for 1893. 483-514. Also in Transactions of the Inverness Scientific Society and Field Club (1888-1895) 4, 300-339.

Khatwa, A., Tulaczyk, S. 2001. Microstructural interpretations of modern and Pleistocene subglacially deformed sediments: the relative role of parent material and subglacial processes. Journal of Quaternary Science 16, 507-517.

Kjær, K.H., Larson, E., van der Meer, J., Ingólfsson, Ò., Krüger, J., Benediktsson, İ.Ö., Knudsen, C.G., Schomacker, A. 2006. Subglacial decoupling at the 
sediment/bedrock interface: a new mechanism for rapid flowing ice. Quaternary Science Reviews 25, 2704-2712.

Menzies, J. 2000. Micromorphological analyses of microfabrics and microstructures indicative of deformation processes in glacial sediments. In Maltman, A.J., Hubbard, B., Hambrey, J.M. (Eds) Deformation of Glacial Materials. Geological Society, London, Special Publication 176, 245-257.

Menzies, J., van der Meer, J.J.M., Rose, J. 2006. Tills - as a glacial “tectomict”, its internal architecture and the development of a "typing” method for till differentiation. Geomorphology 75, 172-200.

Merritt, J.W. 1992. The high-level marine shell-bearing deposits of Clava, Invernessshire, and their origin as glacial rafts. Quaternary Science Reviews 11, 759-79.

Merritt, J.W., Auton, C.A., Firth, C.R. 1995. Ice-proximal glaciomarine sedimentation and sea-level change in the Inverness area, Scotland: A review of the deglaciation of a major ice stream of the British Late Devensian ice sheet. Quaternary Science Reviews 14, 289-329.

Merritt, J.W., Auton, C.A., Connell, E.R., Hall, A.M., Peacock, J.D. 2003. The Cainozoic geology and landscape evolution of north-east Scotland. Memoir of the British Geological Survey, Sheets 66E, 67, 76E, 77, 86E, 87W, 87E, 95, 96W, 96E and 97 (Scotland).

Moran, S.R. 1971. Glacitectonic structures in drift. In Goldthwaite, R.P. (Ed). Till: A Symposium. Ohio State University Press, 127-148.

Moran, S.R., Clayton, L., Hooke, R.L., Fenton, M.M., Andriashek, L.D. 1980. Glacier-bed landforms of the prairie region of North America. Journal of Glaciology 25, 457-476.

Peacock, J.D. 1975. Depositional environment of glacial deposits at Clava, north-east Scotland. Bulletin of the Geological Survey of Great Britain 49, 31-37.

Peacock, J.D. 1999. The pre-Windermere Interstadial (Late Devensian) raised marine strata of eastern Scotland and their macrofauna: A review. Quaternary Science Reviews 18, 1655-1679.

Peacock, J.D. 2002. Macrofauna and palaeoenvironment of marine strata of Windermere Interstadial age on the east coast of Scotland. Scottish Journal of Geology 38, 32-40. 
Phillips, E.R. 2006. Micromorphology of a debris flow deposit: evidence of basal shearing, hydrofracturing, liquefaction and rotational deformation during emplacement. Quaternary Science Reviews 25, 720-738.

Phillips, E.R., Auton, C.A. 2000. Micromorphological evidence for polyphase deformation of glaciolacustrine sediments from Strathspey, Scotland. In Maltman, A.J. Hubbard, B., Hambrey, J.M. (Eds). Deformation of Glacial Materials. Geological Society, London, Special Publications 176, 279-292.

Phillips, E.R., Merritt, J., Auton, C., Golledge, N. 2007. Microstructures in subglacial and proglacial sediments: understanding faults, folds and fabrics, and the influence of water on the style of deformation. Quaternary Science Reviews 26, 1499-1528.

Rijsdijk, K.F., Owen, G., Warren, W.P., McCarroll, D., van der Meer, J.J.M. 1999. Clastic dykes in over-consolidated tills: Evidence for subglacial hydrofracturing at Killiney Bay, eastern Ireland. Sedimentary Geology 129, 111-126.

Ruszczynska-Szenajch, H. 1987. The origin of glacial rafts: detachment, transport, deposition. Boreas 16, 101-112.

Sissons, J.B. 1967. The Evolution of Scotland's Scenery. Oliver and Boyd, Edinburgh, London.

Stalker, A.MacS. 1976. Megablocks, or the enormous erratics of the Albertan Prairies. Geological Survey of Canada, Paper 76-1C, 185-188.

Sutherland, D.G. 1981. The high-level shell beds of Scotland and the build-up of the last Scottish ice sheet. Boreas 10, 247-254.

van der Meer, J.J.M. 1987. Micromorphology of glacial sediments as a tool in distinguishing genetic varieties of till. In Kujansuu, R., Saarnisto, M. (Eds). INQUA Till Symposium, Finland 1985. Geological Survey of Finland, Special Paper 3, 77-89. van der Meer, J.J.M. 1993. Microscopic evidence of subglacial deformation. Quaternary Science Reviews 12, 553-587.

van der Meer, J.J.M., Laban, C. 1990. Micromorphology of some North Sea till samples, a pilot study. Journal of Quaternary Science 5, 95-101.

van der Meer, J.J.M., Rabassa, J.O., Evenson, E.B. 1992. Micromorphological aspects of glaciolacustrine sediments in northern Patagonia, Argentina. Journal of Quaternary Science 7, 31-44.

van der Meer, J.J.M., Kjaer, K., Krüger, J. 1999. Subglacial water escape structures and till structure, Sléttjökull, Iceland. Journal of Quaternary Science 14, 191-415. 
van der Meer, J.J.M., Menzies, J., Rose, J. 2003. Subglacial till: the deforming glacier bed. Quaternary Science Reviews 22, 1659-1685.

van der Wateren, F.M. 1995. Process of glaciotectonism. In Menzies, J. (Ed). Glacial Environments. Modern Glacial Environments: Processes, Dynamics and Sediments vol. 1. Butterworth-Heinemann, Oxford, 309-335.

van der Wateren, F.M., Kluiving, S.J., Bartek, L.R. 2000. Kinematic indicators of subglacial shearing. In Maltman, A.J., Hubbard, B., Hambrey, J.M. (Eds). Deformation of Glacial Materials. Geological Society, London, Special Publications 176, 259-291.

\section{Figures}

Fig. 1. Simplified geological map of the Clava area showing the locations of the main sections studied (after Merritt, 1992; British Geological Survey, 1997). Insets - show the location of the study area and main ice flow direction indicators from the district.

Fig. 2. (a) Section through the Pleistocene glaciogenic sequence exposed in the Clava Main Pit showing the main deformation structures. (b) Highly deformed Clava Shelly Clay exposed near the bottom of the section. Bedding within the clay has locally been transposed by a glacitectonic foliation. Both bedding and foliation are off set by a set of small-scale normal and reverse faults. Location of photograph shown on Fig. 2a.

Fig. 3. (a) Section through the Pleistocene glaciogenic sequence exposed in Cassie Burn (Section III of Merritt, 1992). The locations of samples N4691 and N4692 are also shown. (b) Large-scale monoclinal folds which deform bedding within the thrustbound wedge of Clava Sand. (c) Tight, gently inclined fold developed at the tip of a thrust. The location of (b) and (c) are shown on Fig. 3a.

Fig. 4. Prominent SE-directed thrust deforming the basal part of the Clava Gravel (Cassie Burn section III, after Merritt 1992). The this is marked by a 20 to $30 \mathrm{~cm}$ thick 'high strain zone' composed of finely layered sand, silt and clay. The location of samples N4691 and N4692 are is also shown. Location of photograph is shown in Fig. 3a.

Fig. 5. (a, b and c) Laterally extensive hydrofracture systems developed within the Clava Sand exposed in the Clava Main Pit. These hydrofractures are truncated by a highly deformed zone towards the top of the Clava Sand, immediately below the base of the overlying Finglack Till Formation (a and c). The location of samples N4693 and N4694, N4695 and N4696 are also shown (b and c). 
Fig. 6. Network of cross-cutting, subhorizontal to subvertical hydrofractures locally developed within the Finglack Till Formation (Cassie Burn section VI, after Merritt 1992). The hydrofractures are filled by pale coloured, finely laminated sand, silt and clay.

Fig. 7. (a) Annotated scan of thin section N4691 showing main features developed within the apparent 'high strain zone' marking a major thrust developed near the base of the Clava Gravel. (b) Annotated scan of thin section N4693 showing main features developed within the laminated sand, silt and clay fill present within the subhorizontal, bedding-parallel section of a laterally extensive hydrofracture system present within the Clava Sand (scale bar $=10 \mathrm{~mm}$ ). The finely layered sand, silt and clay which dominates the sample is cut by a later steeply dipping clay and silt-filled hydrofracture.

Fig. 8. (a) Annotated scan of thin section N4694 showing main features developed within the laminated sand, silt and clay fill present within the subhorizontal, beddingparallel section of a laterally extensive hydrofracture system present within the Clava Sand (scale bar $=10 \mathrm{~mm}$ ). (b) Annotated scan of thin section N4695 showing main features developed within the laminated sand, silt and clay fill present within the subhorizontal, bedding-parallel section of a laterally extensive hydrofracture system present within the Clava Sand (scale bar $=10 \mathrm{~mm}$ ). The finely layered sand, silt and clay which dominates this sample is cut by a later steeply dipping sand, silt and clayfilled hydrofracture.

Fig. 9. Annotated scan of thin section N4696 showing main structures within the complex, cross-cutting sequence of sand, silt and clay fills present within the subvertical section of a laterally extensive hydrofracture system present within the Clava Sand (scale bar $=10 \mathrm{~mm}$ ).

Fig. 10. Schematic section (not to scale) through the hydrofracture system developed within the Clava Sand Member. The figure shows the cross-cutting relationships developed between the approximately layer-parallel sand layers and steeply inclined to subvertical sand, silt and clay filled hydrofractures. For details see Figs. 7, 8 and 9.

Fig. 11. (a) Schematic cross-section (not to scale) through the deformed, ice-rafted sequence exposed at Clava. The relative positions of the main sections described in the text are also shown. (b) Simplified model of the ice-rafted sequence at Clava showing the main bounding thrusts. 
Fig. 12. (a) Map showing the possible extent of the raft of Clava Shelly Formation exposed at Clava. (b) and (c) Simplified reconstructions showing the transport of the Clava Shelly Formation rafts from their potential source in the Great Glen to their emplacement at Clava (after Merritt, 1992).

Fig. 13. Cartoon showing the proposed model for the initial detachment, transport and subsequent accretion of the rafts of marine shelly sediments exposed at Clava. 


\section{Tables}

Table 1. Lithostratigraphy of the glacigenic sequence exposed in the Clava area (after Merritt, 1992; Fletcher et al., 1996). * members of the Clava Shelly Formation.

\begin{tabular}{|l|l|c|c|c|c|}
\hline \multicolumn{2}{|l|}{ Lithostratigraphical unit } & Main Pit & $\begin{array}{c}\text { Finglack } \\
\text { Burn section }\end{array}$ & $\begin{array}{c}\text { Cassie Burn } \\
\text { section III }\end{array}$ & $\begin{array}{c}\text { Cassie Burn } \\
\text { section VI }\end{array}$ \\
\hline 8 & Finglack Till Formation (FTF) & + & + & + & + \\
\hline 7 & Clava Gravel Member* (CGM) & & & + & \\
\hline 6 & Clava Sand Member* (CSM) & + & + & & \\
\hline 5 & $\begin{array}{l}\text { Clava Shelly Clay Member* } \\
\text { (CSCM) }\end{array}$ & + & + & + & \\
\hline 4 & $\begin{array}{l}\text { Clava Shelly Till Member* } \\
\text { (CSTM) }\end{array}$ & & + & & \\
\hline 3 & $\begin{array}{l}\text { Drummore Gravel Formation } \\
\text { (DGF) }\end{array}$ & + & + & & \\
\hline 2 & Cassie Till Formation (CTF) & + & & near surface & \\
\hline 1 & Bedrock & + & & & + \\
\hline
\end{tabular}


Table 2. Correlations between the various deformation, hydrofracturing and liquefaction events recognised in samples N4693, N4694, N4695 and N4696 collected from Clava 'Main Pit'.

\begin{tabular}{|c|c|c|c|c|}
\hline & \multicolumn{4}{|c|}{ Sample Number } \\
\hline & N4693 & N4694 & N4695 & N4696 \\
\hline \multicolumn{5}{|c|}{ Event 1 - main phase of layer-parallel thrusting } \\
\hline Stage 1 & $\begin{array}{l}\text { bedding-parallel } \\
\text { thrusting/shearing } \\
\text { partitioned into } \\
\text { clay-rich horizons }\end{array}$ & $\begin{array}{l}\text { bedding-parallel } \\
\text { thrusting/shearing } \\
\text { partitioned into } \\
\text { clay-rich horizons }\end{array}$ & $\begin{array}{l}\text { bedding-parallel } \\
\text { thrusting/shearing } \\
\text { partitioned into } \\
\text { clay-rich horizons }\end{array}$ & $\begin{array}{l}\text { bedding-parallel } \\
\text { thrusting/shearing } \\
\text { partitioned into } \\
\text { clay-rich horizons }\end{array}$ \\
\hline Stage 2 & & & $\begin{array}{l}\text { disharmonic folding } \\
\text { and brecciation in } \\
\text { clay-silt layers and } \\
\text { liquefaction } \\
\text { intercalated } \\
\text { laminae }\end{array}$ & \\
\hline \multicolumn{5}{|c|}{$\begin{array}{c}\text { Event } 2 \text { - repeated injection of fluidised sediment parallel to layering with minor } \\
\text { thrusting/faulting }\end{array}$} \\
\hline Stage 3 & $\begin{array}{lr}\text { injection of SS1 } \\
\begin{array}{l}\text { sand parallel } \\
\text { layering }\end{array}\end{array}$ & $\begin{array}{lr}\text { injection of } & \text { SS1 } \\
\text { sand parallel } & \text { to } \\
\text { layering } & \end{array}$ & $\begin{array}{l}\text { injection of coarse } \\
\text { CS1 sand }\end{array}$ & $\begin{array}{l}\text { injection of weakly } \\
\text { laminated SS1 sand } \\
\text { parallel to layering }\end{array}$ \\
\hline Stage 4 & & & $\begin{array}{l}\text { injection of SS4 } \\
\text { sand }\end{array}$ & \\
\hline Stage 5 & & $\begin{array}{l}\text { renewed layer- } \\
\text { parallel thrusting } \\
\text { and modification of } \\
\text { the margins of SS1 } \\
\text { sand }\end{array}$ & $\begin{array}{l}\text { renewed layer- } \\
\text { parallel thrusting }\end{array}$ & \\
\hline Stage 6 & $\begin{array}{l}\text { injection of SS2 } \\
\text { sand cross-cutting } \\
\text { bedding and fills a } \\
\text { sub-vertical water- } \\
\text { escape conduit }\end{array}$ & $\begin{array}{l}\text { injection of SS2 } \\
\text { cross-cutting } \\
\text { bedding }\end{array}$ & & \\
\hline Stage 7 & $\begin{array}{l}\text { injection of highly } \\
\text { irregular shaped } \\
\text { layers of coarse } \\
\text { CS1 sand }\end{array}$ & & $\begin{array}{l}\text { injection of coarse } \\
\text { CS1 sand }\end{array}$ & \\
\hline Stage 8 & $\begin{array}{l}\text { injection of weakly } \\
\text { laminated SS3 sand } \\
\text { which pinches out } \\
\text { laterally }\end{array}$ & $\begin{array}{l}\text { injection of SS3 } \\
\text { cross-cutting } \\
\text { bedding }\end{array}$ & & \\
\hline Stage 9 & & $\begin{array}{l}\text { normal faulting and } \\
\text { boudinage of SS2 } \\
\text { and SS3 sand layers }\end{array}$ & $\begin{array}{l}\text { localised normal } \\
\text { and reverse faulting }\end{array}$ & \\
\hline Stage 10 & $\begin{array}{l}\text { injection of clay } \\
\text { microbreccia (MB) } \\
\text { and formation of } \\
\text { funnel-shaped } \\
\text { water-escape } \\
\text { conduit }\end{array}$ & $\begin{array}{l}\text { injection of clay } \\
\text { microbreccia (MB) }\end{array}$ & & \\
\hline Stage 11 & $\begin{array}{lr}\text { injection } & \text { of } \\
\text { laminated } & \text { and }\end{array}$ & $\begin{array}{l}\text { injection of weakly } \\
\text { laminated SS4 sand }\end{array}$ & $\begin{array}{l}\text { injection of the } \\
\text { massive weakly }\end{array}$ & \\
\hline
\end{tabular}




\begin{tabular}{|c|c|c|c|c|}
\hline & $\begin{array}{l}\text { reverse graded SS4 } \\
\text { cross-cutting } \\
\text { bedding }\end{array}$ & $\begin{array}{ll}\text { cross } & \text { cutting } \\
\text { bedding } & \end{array}$ & $\begin{array}{l}\text { laminated SS1 sand } \\
\text { cross-cutting } \\
\text { bedding }\end{array}$ & \\
\hline Stage 12 & $\begin{array}{l}\text { injection of SS5 } \\
\text { sand }\end{array}$ & $\begin{array}{l}\text { injection of the } \\
\text { coarse CS1 sand }\end{array}$ & $\begin{array}{l}\text { injection of massive } \\
\text { SS6 sand }\end{array}$ & \\
\hline Stage 13 & & $\begin{array}{l}\text { reactivation of } \\
\text { earlier developed } \\
\text { normal and reverse } \\
\text { faults }\end{array}$ & $\begin{array}{l}\text { injection of weakly } \\
\text { laminated and } \\
\text { reverse graded SS3 } \\
\text { sand cross-cutting } \\
\text { bedding }\end{array}$ & \\
\hline Stage 14 & & $\begin{array}{l}\text { injection of SS5 } \\
\text { sand cross-cutting } \\
\text { bedding }\end{array}$ & $\begin{array}{l}\text { minor reactivation } \\
\text { of normal faults }\end{array}$ & \\
\hline Stage 15 & & & $\begin{array}{l}\text { injection of SS5 } \\
\text { sand }\end{array}$ & \\
\hline \multicolumn{5}{|c|}{ Event 3 - formation of broad, cross-cutting water-escape conduit } \\
\hline Stage 16 & $\begin{array}{l}\text { formation of broad, } \\
\text { moderately inclined } \\
\text { water-escape } \\
\text { conduit and } \\
\text { injection of weakly } \\
\text { laminated F2 sand }\end{array}$ & $\begin{array}{l}\text { formation of broad, } \\
\text { shallowly inclined } \\
\text { water-escape } \\
\text { conduit and } \\
\text { injection of weakly } \\
\text { laminated and } \\
\text { graded F2 sand }\end{array}$ & & $\begin{array}{l}\text { ?disharmonic } \\
\text { folding and } \\
\text { liquefaction of SS2 } \\
\text { sand }\end{array}$ \\
\hline Stage 17 & \begin{tabular}{l}
\multicolumn{2}{l}{ hydrofracturing } \\
within Stage 9 \\
water-escape \\
conduit and \\
deposition of \\
laminated LV1 fill
\end{tabular} & \begin{tabular}{ll}
\multicolumn{2}{l}{ hydrofracturing } \\
within Stage & 12 \\
water-escape \\
conduit and \\
deposition an \\
laminated LV1 fill
\end{tabular} & & \\
\hline Stage 18 & $\begin{array}{l}\text { hydrofracturing } \\
\text { within Stage } 9 \\
\text { water-escape } \\
\text { conduit and } \\
\text { deposition of } \\
\text { laminated LV2 fill }\end{array}$ & $\begin{array}{l}\text { hydrofracturing } \\
\text { within Stage } \\
\text { water-escape } \\
\text { conduit and } \\
\text { deposition of } \\
\text { laminated LV2 fill }\end{array}$ & & \\
\hline \multicolumn{5}{|c|}{ Event 4 - main phase of hydrofracturing } \\
\hline Stage 19 & $\begin{array}{l}\text { hydrofracturing, } \\
\text { steep brittle fracture } \\
\text { and formation of } \\
\text { HF1 breccia fill }\end{array}$ & & & $\begin{array}{l}\text { brecciation and } \\
\text { injection of coarse } \\
\text { CS1 sand into } \\
\text { breccia along the } \\
\text { main water-escape } \\
\text { conduit }\end{array}$ \\
\hline Stage 20 & & & & $\begin{array}{l}\text { normal faulting of } \\
\text { CS1 sand ?sediment } \\
\text { collapse within the } \\
\text { water-escape } \\
\text { conduit }\end{array}$ \\
\hline Stage 21 & & & & $\begin{array}{l}\text { injection of graded } \\
\text { CS2 sand }\end{array}$ \\
\hline Stage 22 & & & & $\begin{array}{l}\text { injection of the } \\
\text { clast- to matrix- } \\
\text { supported CS3 sand } \\
\text { fed by a narrow off- } \\
\text { shoot of main } \\
\text { water-escape } \\
\text { conduit }\end{array}$ \\
\hline
\end{tabular}




\begin{tabular}{|c|c|c|c|}
\hline Stage 23 & & & $\begin{array}{l}\text { hydrofracturing, } \\
\text { deposition of } \\
\text { laminated LF1 fill }\end{array}$ \\
\hline Stage 24 & & & $\begin{array}{l}\text { minor faulting of } \\
\text { LF1 }\end{array}$ \\
\hline Stage 25 & & \multirow{2}{*}{$\begin{array}{l}\text { hydrofracturing, } \\
\text { steep brittle fracture } \\
\text { with internally } \\
\text { complex HF2 } \\
\text { sandy fill }\end{array}$} & $\begin{array}{l}\text { injection of the } \\
\text { internally complex } \\
\text { HF1 sandy fill into } \\
\text { water-escape } \\
\text { conduit }\end{array}$ \\
\hline Stage 26 & $\begin{array}{l}\text { injection of } \\
\text { internally complex } \\
\text { HF2 sandy fill into } \\
\text { water-escape } \\
\text { conduit }\end{array}$ & & $\begin{array}{l}\text { injection of sandy } \\
\text { HF2 fill into the } \\
\text { main water-escape } \\
\text { conduit }\end{array}$ \\
\hline Stage 27 & $\begin{array}{l}\text { deposition of clay- } \\
\text { rich HF3 fill into } \\
\text { water-escape } \\
\text { conduit }\end{array}$ & $\begin{array}{l}\text { hydrofracturing, } \\
\text { steep brittle fracture } \\
\text { and development of } \\
\text { HF3 laminate clay- } \\
\text { rich fill }\end{array}$ & $\begin{array}{l}\text { deposition of clay- } \\
\text { rich HF3 fills into } \\
\text { the main water- } \\
\text { escape conduit }\end{array}$ \\
\hline Stage 28 & & $\begin{array}{l}\text { injection of SS7 } \\
\text { sand into main } \\
\text { hydrofracture } \\
\text { system }\end{array}$ & $\begin{array}{l}\text { injection of SS7 } \\
\text { sand into main } \\
\text { hydrofracture } \\
\text { system }\end{array}$ \\
\hline
\end{tabular}




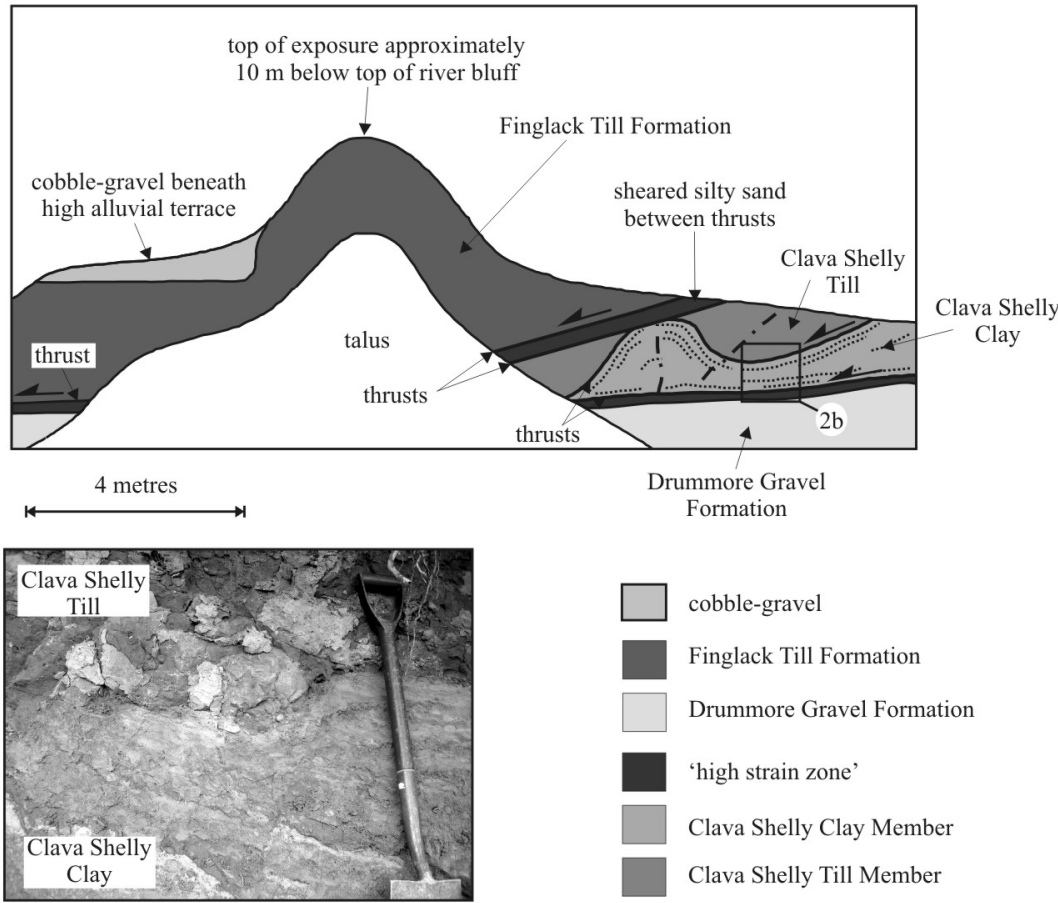

$\sim$ thrusts $\leftarrow$ direction of fault movement $\ldots-$ fold axial surface $\ldots . . . \cdots \cdot \cdots \cdot$ bedding 


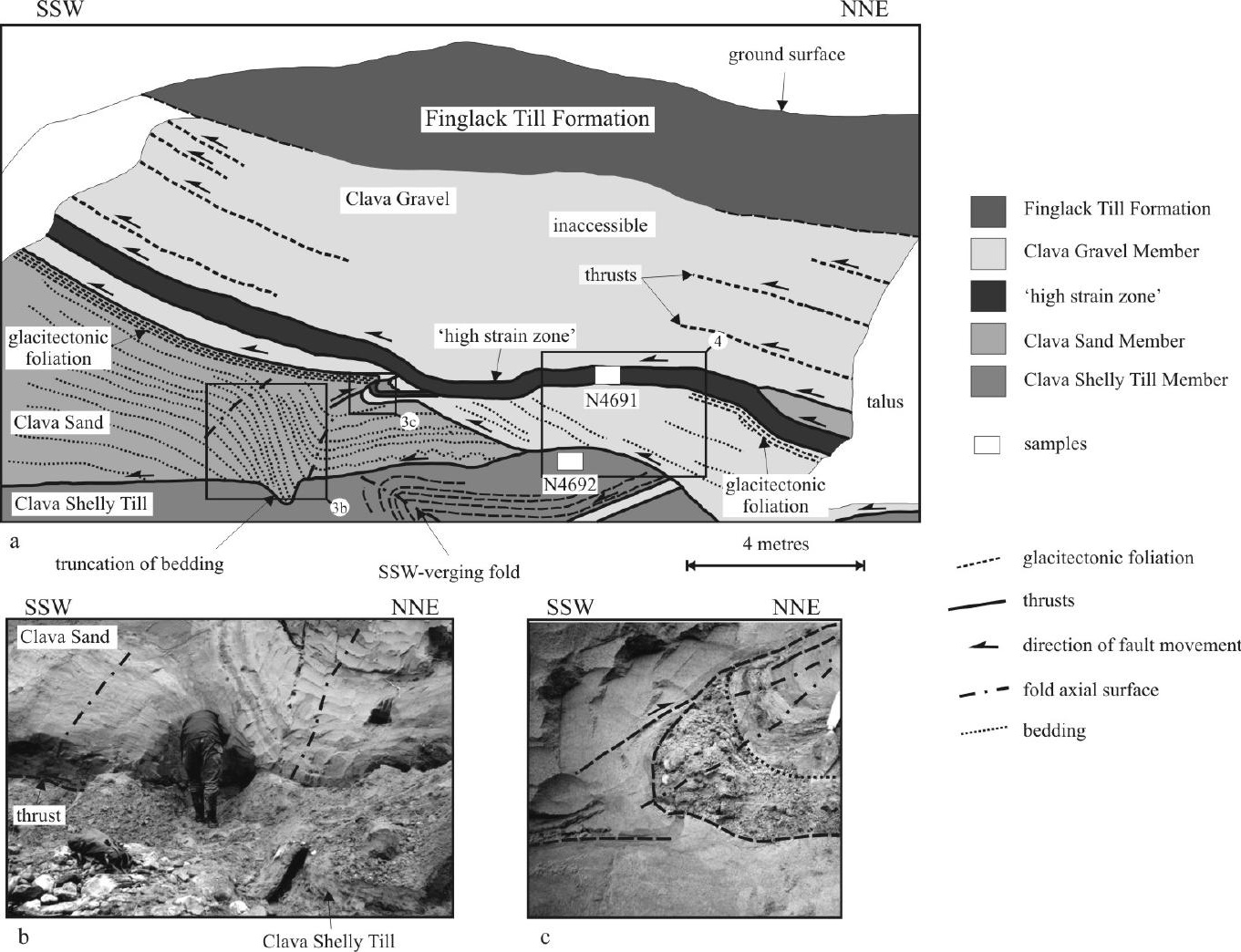




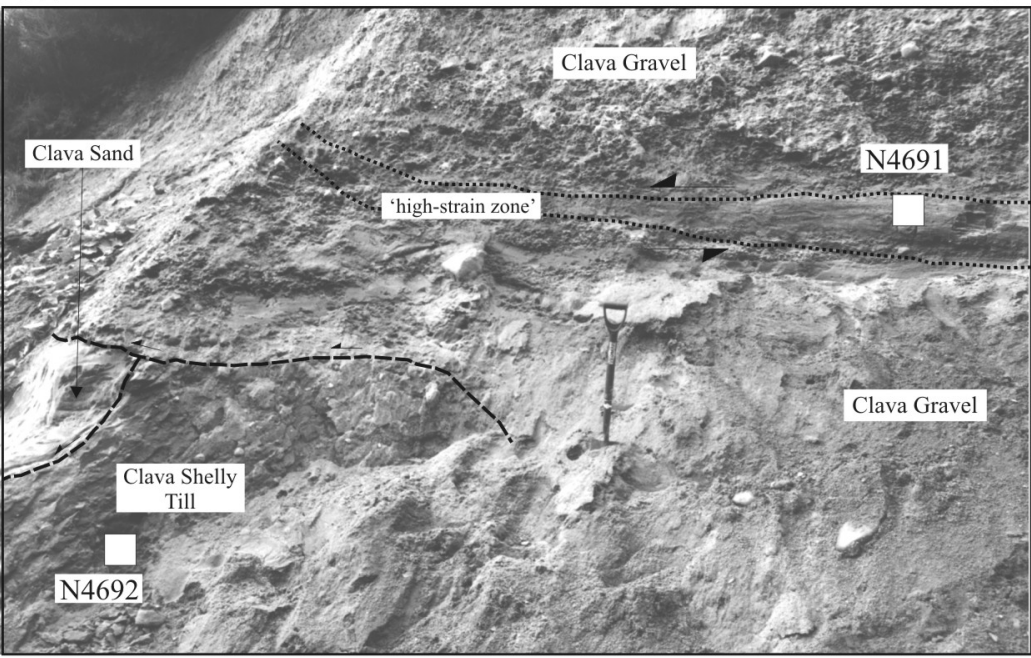
margin of 'high-strain zone' _-_' thrust 

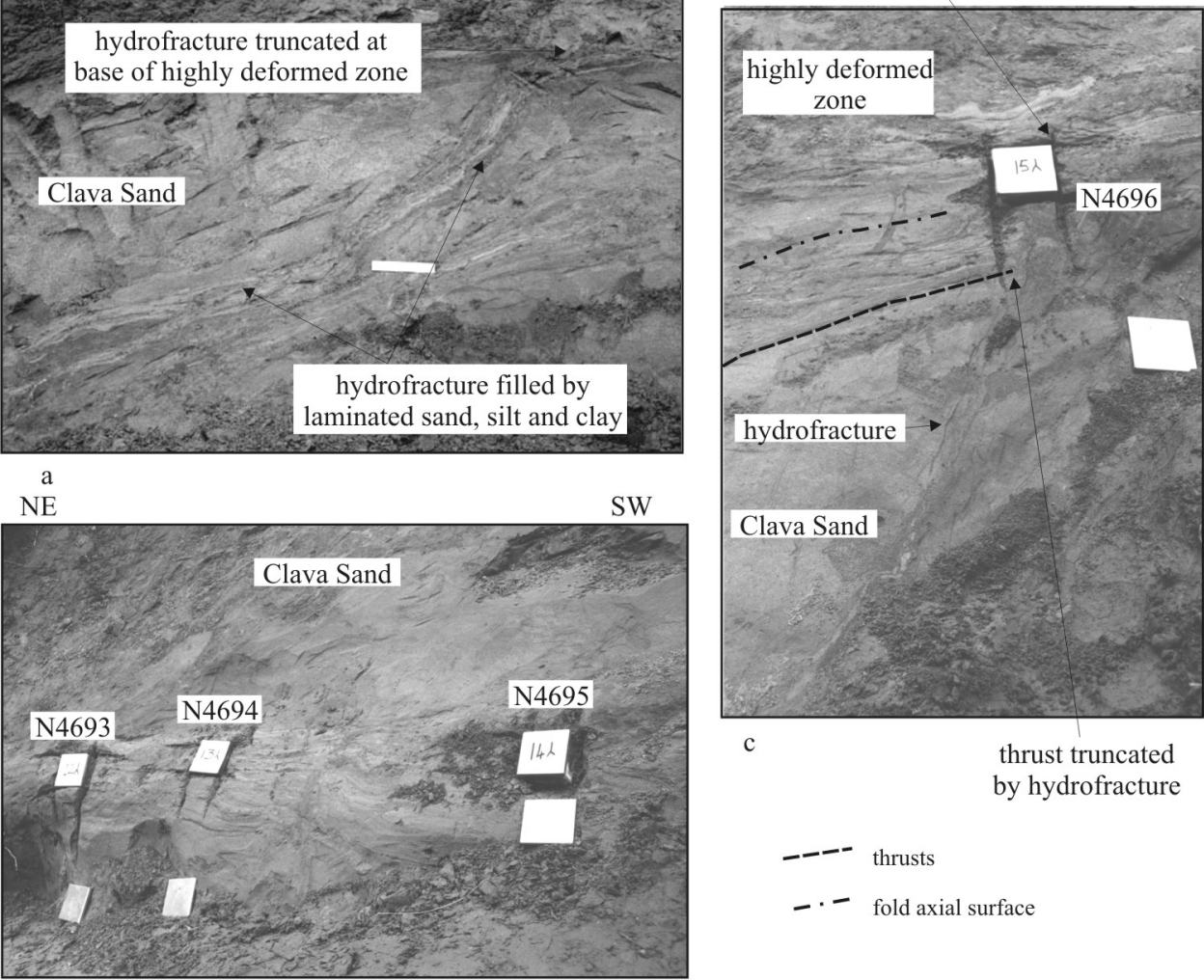

c

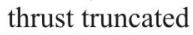
by hydrofracture

b 


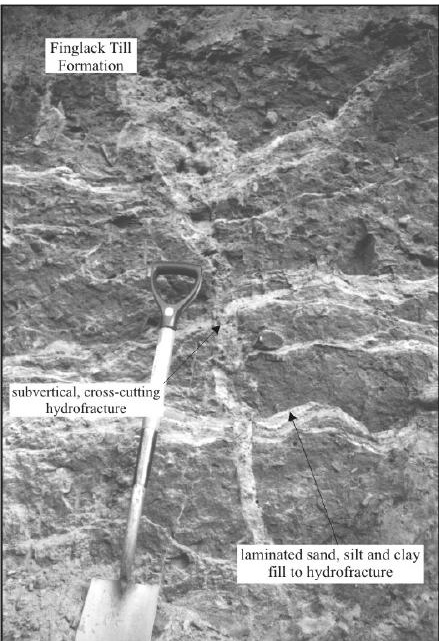




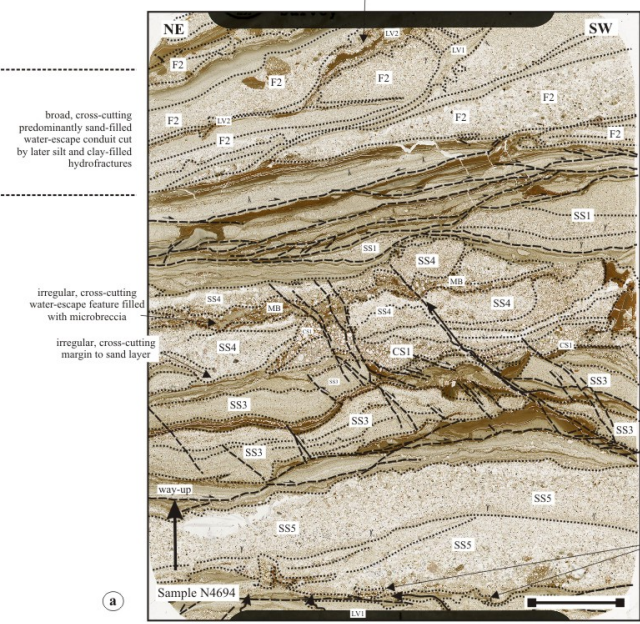

broud, cross-cutting

predominantly sand-filled

water-escape conduit eut

by later silt and clay-filled

hydrofractures

layes-parallel thrusts

and shears concentrated

into clay and silt-rich layers

zone of rormal faulting

reverse faulting and

aticnuation of sand layers

subvertical sand, silt

and clay-fillod hydrofracture

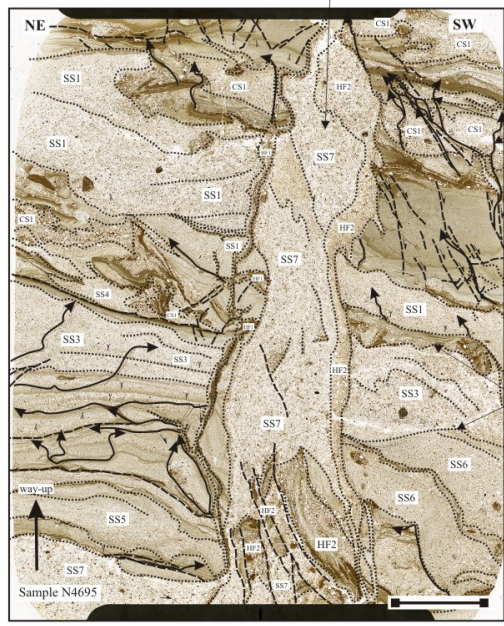

anastomosing clay-filled

sand layer eross-cuttin

sedimentary lamination

deformation structures

highly disrupted lamination clay and silt, cut by irregulat patches of coarse-grained sand

irregular, cross-cutting clay-filled watcr-escape duits disharmonic folding and convolute lamination

(b) 
highly disrupted lamination in clay and silt, cut by irregular patches of coarse-grained sand

sand layer cross-cutting sedimentary lamination and earlier developed deformation structures

inclined, disharmonic fold with overprinting of the a diffuse lamination on the overtumed limb

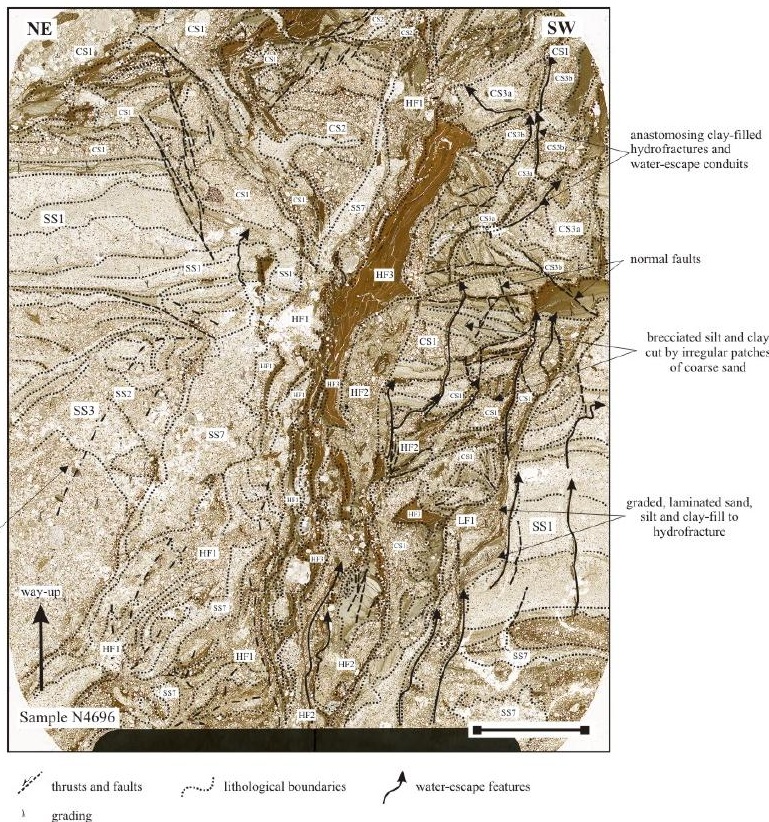




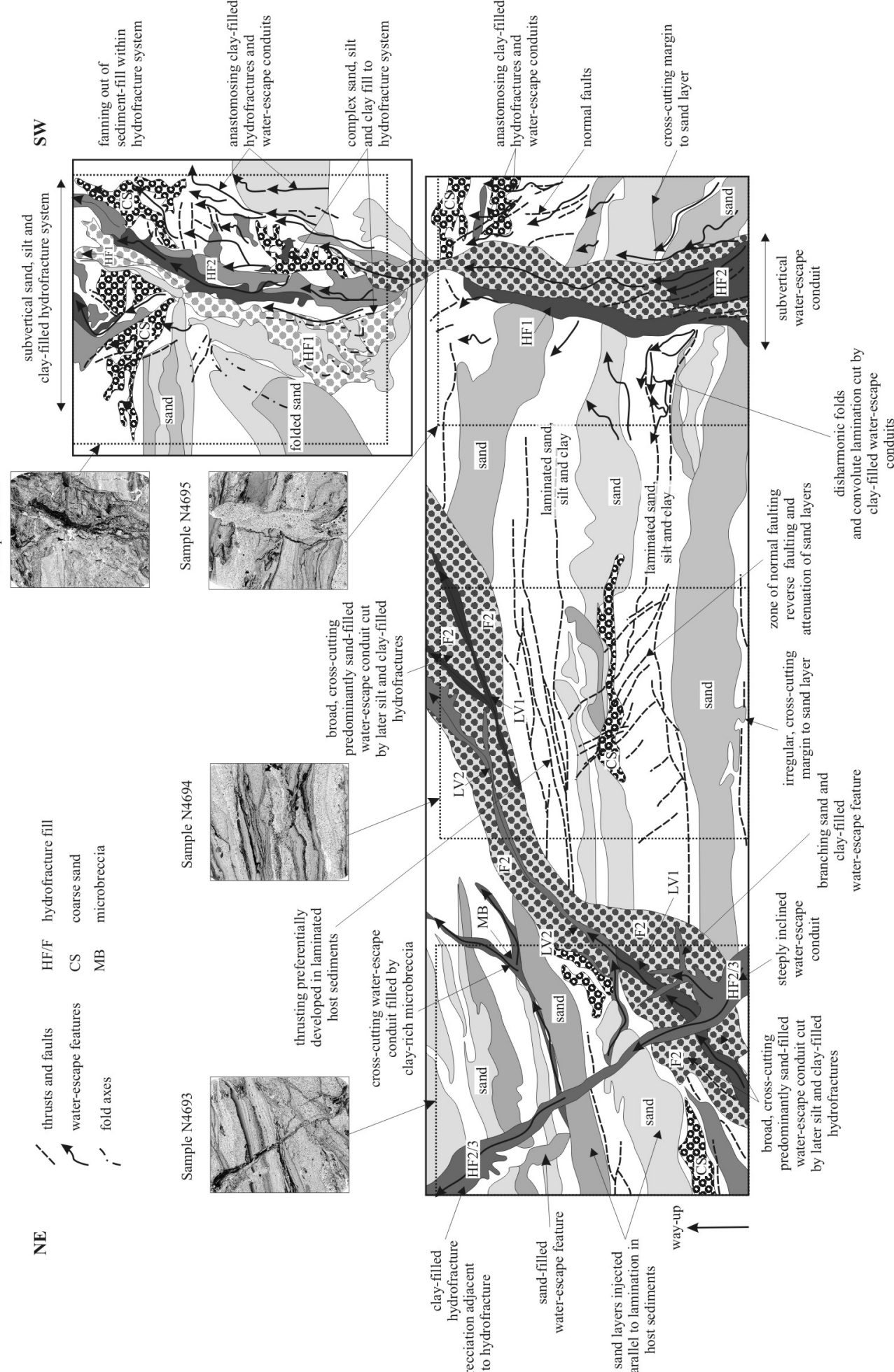




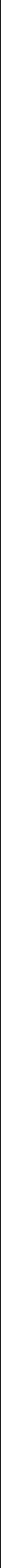


Stage 1: initial detachment of rafts

\section{SW}

ice movement direction

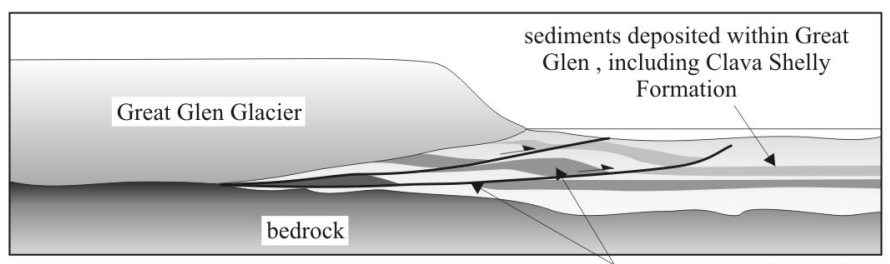

\section{Stage 2: subglacial to ice marginal transport of rafts}

proglacial to subglacial folding and thrusting
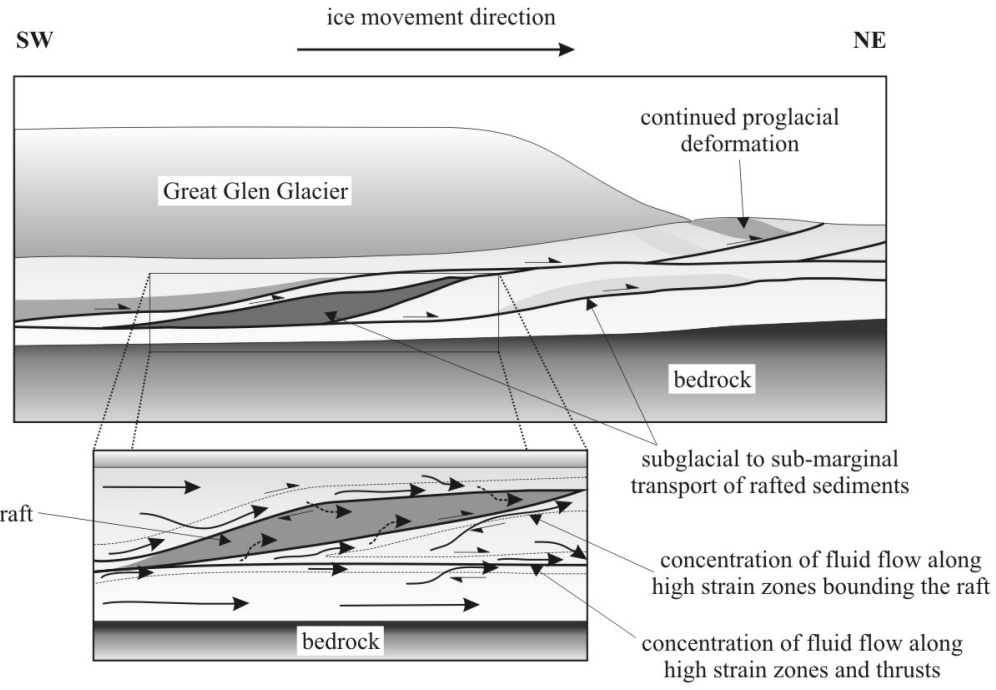

Stage 3: accretion of rafts and formation of duplex

ice movement direction

NW

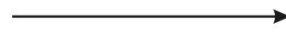

SE

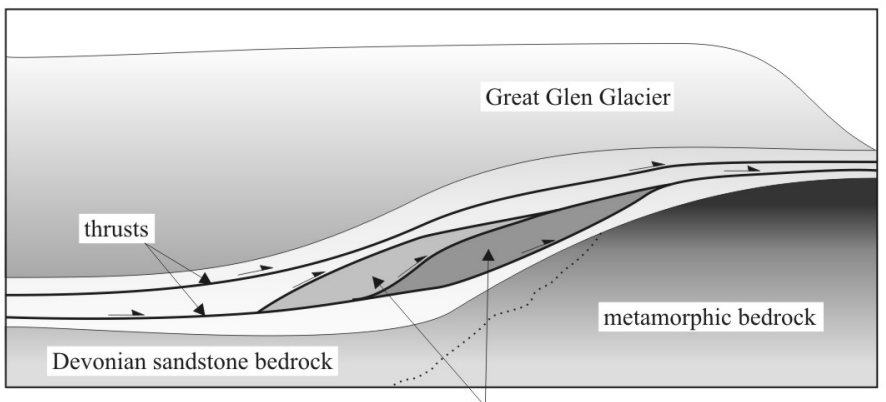

thrust-bound rafts forming a duplex immediately adjacent to bedrock high

migration of pore water through sediments

$\mp$ sense of shear in high strain zones hyrdofracturing and migration of pore water into raft $\quad \ldots . . . . .$. margins of high strain zones 